\title{
Benthic carbon metabolism in southeast Australian estuaries: habitat importance, driving forces, and application of artificial neural network models
}

\author{
D. Maher*, B. D. Eyre \\ Centre for Coastal Biogeochemistry, School of Environmental Science and Management \\ Southern Cross University, Lismore, New South Wales 2480, Australia
}

\begin{abstract}
Benthic gross primary productivity (GPP), net primary production (NP), and respiration $(\mathrm{R})$ were measured seasonally in each of 12 major benthic habitats in 3 southeast Australian estuaries, along with a suite of biological, physical, and chemical parameters to construct a benthic carbon budget and to elucidate controls over benthic metabolism. We also tested the performance of an artificial neural network (ANN) model in predicting benthic metabolism from the suite of measured parameters, and compared model performance to traditional stepwise regression methods. Carbon budgets indicated that macrophyte communities made the greatest contribution to whole system benthic metabolism (51 to $79 \%$ of gross productivity and 38 to $74 \%$ of respiration), and net benthic metabolism of the 3 estuaries ranged from -25 to $\sim 90 \mathrm{~g} \mathrm{C} \mathrm{m}^{-2} \mathrm{yr}^{-1}$. Metabolism in non-macrophyte communities was tightly coupled to light, temperature, organic matter supply, and benthic algal biomass, and metabolism in macrophyte communities was coupled predominantly to temperature and light. ANN outperformed stepwise regression for all benthic metabolic parameters in both macrophyte and non-macrophyte habitats. Root mean square errors of ANN were up to 3-fold lower than stepwise regression models, indicating the potential use of ANN in modeling ecosystem-scale metabolism. We used ANN models to predict systemwide changes in benthic net production associated with an increase in temperature of 1 to $2^{\circ} \mathrm{C}$. Model results indicate that system-wide net production increased with temperature, indicating that carbon burial in, and/or export from estuaries may increase as a result of increasing water temperature associated with climate change.
\end{abstract}

KEY WORDS: Benthic metabolism · Estuary $\cdot$ Artificial neural network $\cdot$ Climate change $\cdot$ Seagrass Resale or republication not permitted without written consent of the publisher

\section{INTRODUCTION}

Estuaries are among the most productive marine ecosystems in the world (Underwood \& Kromkamp 1999) and have been ranked, on a per unit area basis, as the most economically valuable ecosystems (Costanza et al. 1997). The productivity of estuaries is derived from a diverse assemblage of aquatic primary producers, ranging from unicellular algae and phototrophic bacteria (generally dominated by diatoms, dinoflagellates, and cyanobacteria) to angio- sperms (seagrasses, mangroves, and saltmarshes). The fixation of carbon by these autotrophs, along with allochthonous inputs of organic matter from terrestrial and riverine sources, provides the base of the estuarine food-web. The relative contribution of each of these organic matter sources controls estuarine trophodynamics (Duarte \& Cebrian 1996, McClelland \& Valiela 1998).

The productivity of estuarine ecosystems can be modified by anthropogenic pressures. Increased delivery of nutrients through urban and agricultural 
development can lead to higher rates of ecosystem productivity and a shift from slow-growing plants (e.g. seagrasses) to fast growing algae (e.g. phytoplankton and ephemeral macroalgae) that are better adapted to high nutrient concentrations (Borum \& Sand-Jensen 1996, Hauxwell \& Valiela 2004, McGlathery et al. 2007). Further, benthic productivity may be reduced through light limitation associated with increased phytoplankton biomass in the water column, while increased organic loading to the benthos has led to shifts in benthic macrofaunal biomass and composition, and has increased hypoxic and anoxic environments in estuarine ecosystems (Diaz \& Rosenberg 1995). Shifts in primary producer composition can have large and broad implications for trophic dynamics and biogeochemical cycles within a system. For example, seagrass loss in coastal systems can lead to a decrease in fish abundance, biomass, and diversity (Jenkins et al. 1997, Hughes et al. 2002, Pihl et al. 2006), and a shift from slow-growing, nutrient-poor macrophytes to nutrient-rich microalgae reduces carbon accumulation within a system, as herbivory and organic matter recycling rates increase (Mann 1988, Cebrian 2002). Changes in carbon benthic metabolism in turn influences key ecosystem process such as denitrification rates (Eyre $\&$ Ferguson 2009) and DOC fluxes (Maher \& Eyre 2010, 2011).

While much research has been undertaken on estuarine carbon cycling, significant information gaps still exist. For example, few studies have looked at the contribution of different benthic habitats to ecosystem metabolism (e.g. Moncreiff et al. 1992, Stutes et al. 2007, Eyre et al. 2011). In addition, most studies on estuarine metabolism have been carried out in northern hemisphere temperate systems, which means global estimates on estuarine metabolism are subject to large uncertainties (Hopkinson \& Smith 2005). Several studies have characterized estuaries as heterotrophic ecosystems, i.e. rates of carbon respiration exceed carbon fixation (Smith \& Hollibaugh 1993, Gattuso et al. 1998). Both of these reviews included only one system from the southern hemisphere (Spencer Gulf, Australia; Smith \& Veeh 1989), and this was one of the few autotrophic systems. Metabolism of southern hemisphere estuaries may differ from northern hemisphere estuaries due to climatic, hydrologic, and anthropogenic differences; clearly a better understanding of estuarine metabolism within these systems is required for global carbon models.

In shallow, clear estuaries most of the ecosystem metabolism can occur at the sediment-water inter- face (e.g. Moncreiff et al. 1992, Kaldy et al. 2002, Santos et al. 2004) associated with the complex mosaic of benthic habitat types (Eyre et al. 2011). Typically benthic habitats have been classified as vegetated (e.g. seagrass) and non-vegetated (all other areas) (Barrón et al. 2004, Gazeau et al. 2005, Stutes et al. 2007). However, enhanced nutrient and carbon mineralization rates in bioturbated sediments are well documented (e.g. Kristensen \& Blackburn 1987, Aller \& Aller 1998, Marinelli \& Williams 2003, Webb \& Eyre 2004a, D'Andrea \& DeWitt 2009), and a recent study has highlighted the importance of differentiating so called non-vegetated habitats. Eyre et al. (2011) found a marked difference in the metabolism of different non-seagrass habitats, in particular shoals colonized by the burrowing thalassinidean shrimp Trypaea australiensis (the habitat they termed 'yabby shoals'). They suggested that if the yabby shoals habitat was not implicitly included, their estimation of benthic estuarine net ecosystem metabolism (NEM) (i.e. gross primary productivity [GPP] - respiration [R]) would have been autotrophic (GPP/R 1.1) rather than heterotrophic (GPP/R 0.82). So in spite of the relatively modest area $(\sim 14 \%$ of open water area), it exerted a strong influence on ecosystem metabolism. Therefore when determining ecosystem metabolism, adequate representation of benthic habitats is critical, as less iconic habitats may play a pivotal role in organic matter cycling. Further, the importance of a particular habitat type to ecosystem metabolism is a function of process rate and areal extent (Eyre \& Maher 2011). While many studies have measured process rates within a particular habitat, few have scaled the process rates to habitat area to calculate the relative importance of a particular habitat at the ecosystem scale (Eyre et al. 2011).

While the importance of benthic metabolism estimates for estuarine ecosystems is obvious, the costs and expertise required to adequately measure these processes is high. Therefore there is a need for models of benthic metabolism constructed using readily collected data. Modeling of benthic metabolism has been undertaken using traditional multiple regression (MR) methods, which have yielded reasonable results. For example, Pinckney \& Zingmark (1993) found that a model based on irradiance at the sediment surface, biomass-specific production, and vertical migration of the microalgae community accounted for $\sim 63 \%$ of the variability in observed areal production rates across a range of habitats in a South Carolina estuary. On the other hand, the relationship between productivity and irradiance in seagrasses has been found to be fundamentally non-linear (Zim- 
merman et al. 1994), and therefore modeling productivity of these habitats requires an approach that can effectively model non-linear relationships.

In contrast to traditional linear modeling methods, artificial neural networks (ANNs) are particularly well-suited to modeling complex non-linear systems, and no a priori model definition is required (Lek et al. 1996). ANNs have been used effectively to model a range of ecological processes including phytoplankton production (Scardi 1996, Scardi \& Harding 1999, Belgrano et al. 2001, Millie et al. 2006), fish spawning sites (Lek et al. 1996), and ecosystem metabolic balance (Rochelle-Newall et al. 2007). The most commonly used ANN architecture for ecological modeling is the multilayer feed-forward ANN. The basic structure of this ANN includes input nodes (independent variables), one or more hidden layers of nodes, and one or more output nodes (dependant variable/s). Each input node is linked to each hidden node, and each hidden node is connected to each output node by a series of weighted functions. ANNs are basically a set of nonlinear equations that predict output variables from input variables using layers of linear regressions and sigmoid activation functions. Generally the models are trained with collected data, and the weights between each node are iteratively adjusted by a back propagation method (Rumelhart et al. 1986). One of the major drawbacks with using ANNs is 'overfitting' the model, which leads to a reduced generalization of the results and an inability to use them for predictive purposes. To overcome the problem of overfitting, ANN models are generally cross-validated by omitting a portion of the data during the training phase, which is later introduced to the model for validation purposes. Model efficiency can be gauged by comparing the performance of the training and validation set using statistical techniques ( $R^{2}$ and root mean square error [RMSE]).

The aim of the present study was 2-fold. Firstly, we sought to develop benthic carbon budgets to assess the importance of individual benthic habitat types to the estuarine benthic carbon budget across 3 estuaries, and to determine the physical/biological drivers of benthic metabolism. Secondly, we sought to assess the applicability of ANN to model benthic production and respiration using input variables that are relatively easily collected. We measured benthic net production (NP), GPP, and R seasonally in triplicate cores and chambers at 44 sites encompassing 12 habitat types in 3 estuaries $(n=528)$. These values were then scaled up to the entire system (based on process rate and benthic habitat coverage) to construct benthic carbon budgets. Further, we measured a suite of physical, chemical, and biological parameters to determine drivers of benthic metabolism and to model benthic GPP, NP, and R.

\section{METHODS}

\section{Study area}

The estuaries are located along the southeast Australian coast (Fig. 1) and display distinct differences in terms of estuarine area, water residence time, catchment area, and freshwater inflow (Table 1). The estuaries fall along the estuarine maturity gradient as proposed by Roy et al. (2001), i.e. as estuaries evolve they gradually infill. This leads to a continuum from lake-like estuaries with large central basins (e.g. Wallis Lake) through intermediate stages with a more restricted shallower central basin (e.g. Camden Haven) to a final form of river dominated systems characterized by river channels with a highly restricted/absent central mud basin (e.g. Hastings River).

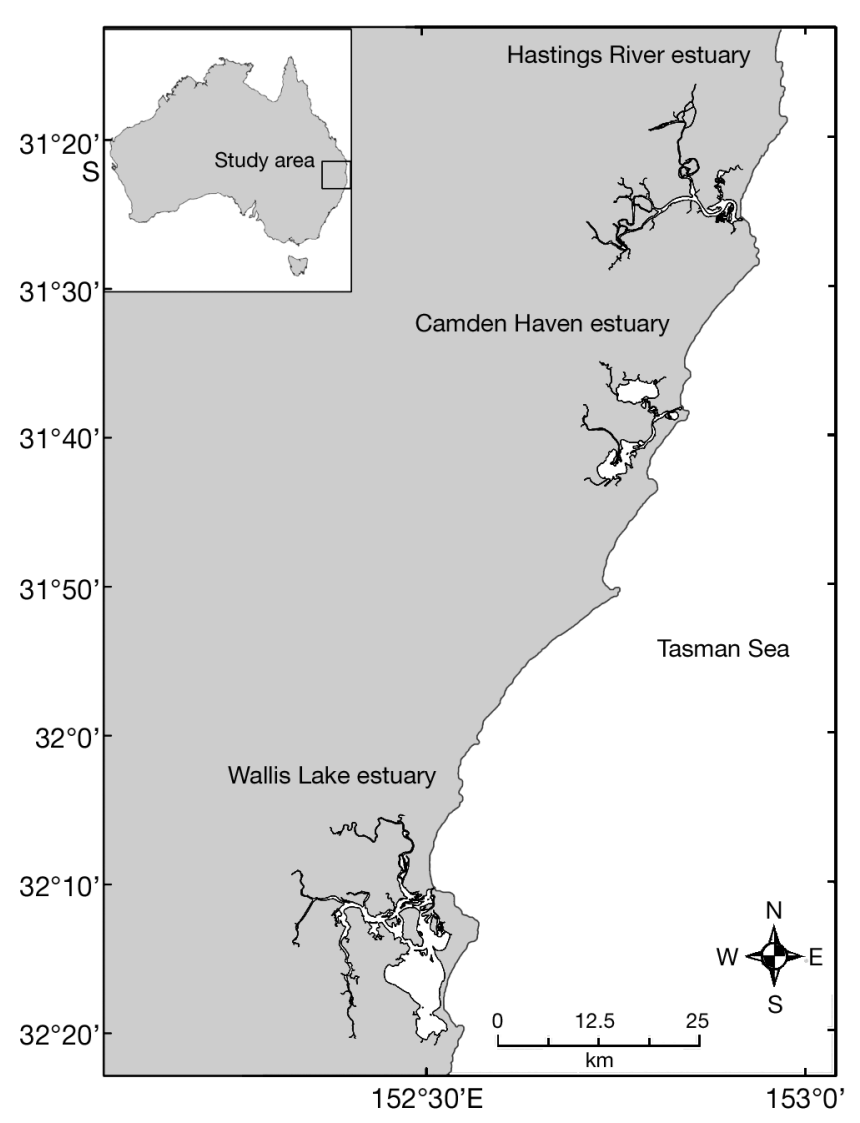

Fig. 1. Study area 
Table 1. Attributes of the study estuaries

\begin{tabular}{|lccccccc|}
\hline Estuary & $\begin{array}{c}\text { Catchment } \\
\text { area }\left(\mathrm{km}^{2}\right)\end{array}$ & $\begin{array}{c}\text { Water } \\
\text { area }\left(\mathrm{km}^{2}\right)\end{array}$ & $\begin{array}{c}\text { Mean } \\
\text { rainfall }(\mathrm{mm})\end{array}$ & $\begin{array}{c}\text { Rainfall during } \\
\text { study }(\mathrm{mm})\end{array}$ & $\begin{array}{c}\text { Annual discharge } \\
(2006-07)(\mathrm{Ml})\end{array}$ & $\begin{array}{c}\text { Mean flushing } \\
\text { time (d) }\end{array}$ & $\begin{array}{c}\text { Catchment } \\
\text { population (n) }\end{array}$ \\
\hline Hastings River & 3595 & 18.62 & 1313 & 998 & 503471 & 6 & 48000 \\
Camden Haven & 440 & 30.05 & 1388 & 1098 & 251483 & 45 & 21000 \\
Wallis Lake & 1420 & 90.45 & 1220 & 1148 & 147883 & $>60$ & 34000 \\
\hline
\end{tabular}

Southeast Australian estuaries receive highly variable freshwater inflow driven on annual scales by the oscillation between summer low pressure systems (east coast lows) bringing significant rainfall and flooding and a semi-permanent winter high pressure belt in the Tasman Sea, leading to cool dry winters. The area is also subject to semi-decadal swings associated with El Niño/La Niña Southern Oscilation (ENSO), which induces below average rainfall conditions under El Niño and above average rainfall during La Niña. During the study period, rainfall was below average (Table 1). Water temperature varied from $\sim 13$ to $\sim 27^{\circ} \mathrm{C}$ during the study, and bottom water oxygen concentrations generally ranged from $\sim 5$ to $\sim 10 \mathrm{mg} \mathrm{l}^{-1}$, although values as low as $1 \mathrm{mg} \mathrm{l}^{-1}$ were recorded at dawn in some seagrass areas. The estuaries have a relatively small catchment population (24000 to 48000 ; Table 1), although there is modification of the catchment land use for agricultural uses (for full description of estuarine stressors see Eyre \& Maher 2010)

\section{Benthic habitats}

Benthic habitats were mapped using a combination of underwater video, diving transects, and remote sensing techniques. Details and maps are presented elsewhere (Eyre \& Maher 2010). Briefly, habitats were based on depth (subtidal, intertidal), sediment grain size (mud-dominant, sand-dominant), geomorphology (channels, depositional basins, shoals), and dominant autotrophs (macroalgae, seagrass, non-seagrass). In addition, seagrass habitats were further delineated based on dominant species (Halophila ovalis, Zostera capricorni, Posidonia australis, and Ruppia megacarpa). This classification scheme lead to a total of 12 habitats being identified in the 3 estuaries (Table 2).

Table 2. Habitat description, \% cover, and number of measurements (in parentheses) made in each habitat during the study

\begin{tabular}{|c|c|c|c|c|}
\hline \multirow[t]{2}{*}{ Habitat } & \multirow[t]{2}{*}{ Description } & \multirow{2}{*}{ Hastings River } & \multirow{2}{*}{$\begin{array}{l}\text { \% cover }(\mathrm{n}) \\
\text { Camden Haven }\end{array}$} & \multirow[b]{2}{*}{ Wallis Lake } \\
\hline & & & & \\
\hline Marine Channel (MC) & $\begin{array}{l}\text { High velocity environment, } \\
\text { clean marine quartz sands }\end{array}$ & $29.36(12)$ & $5.19(24)$ & $1.39(12)$ \\
\hline Zostera (Z) & $\begin{array}{l}\text { Habitat dominated by the seagrass } \\
\text { Zostera capricorni }\end{array}$ & $6.28(12)$ & $18.68(12)$ & $25.33(24)$ \\
\hline Subtidal sand shoals (SS) & $\begin{array}{l}\text { Subtidal shoals comprised of either } \\
\text { fluvial or marine sands }\end{array}$ & $21.91(24)$ & $9.62(24)$ & $16.17(12)$ \\
\hline Subtidal mud shoals (SM) & Subtidal shoals comprised of muds and silts & $13.47(12)$ & $31.91(60)$ & $4.44(12)$ \\
\hline Halophila $(\mathrm{H})$ & $\begin{array}{l}\text { Habitat dominated by the seagrass } \\
\text { Halophila ovalis }\end{array}$ & $2.05(12)$ & $13.27(12)$ & $5.27(12)$ \\
\hline Fluvial muds and sands (FMS) & $\begin{array}{l}\text { Channel habitats in the upper estuary } \\
\text { comprised of fluvial muds and/or sands }\end{array}$ & $20.33(36)$ & $5.05(24)$ & $16.49(36)$ \\
\hline Intertidal sands (IS) & Intertidal shoals comprised of sand & $5.63(12)$ & $6.54(12)$ & $2.23(12)$ \\
\hline Intertidal muds (IM) & Intertidal shoals comprised of muds and silts & ts $0.96(12)$ & $3.22(12)$ & $1.09(12)$ \\
\hline Ruppia (R) & $\begin{array}{l}\text { Habitat dominated by the aquatic } \\
\text { macrophyte Ruppia megacarpa }\end{array}$ & & $6.08(12)$ & $1.09(12)$ \\
\hline Macroalgae (MA) & Habitat dominated by macroalgae & & & $0.83(12)$ \\
\hline Posidonia (P) & $\begin{array}{l}\text { Habitat dominated by the seagrass } \\
\text { Posidonia australis }\end{array}$ & & & $4.43(12)$ \\
\hline Depositional mud basin (DMB) & $\begin{array}{l}\text { Depositional habitats deeper than } 3 \mathrm{~m} \\
\text { characterised by muds and silts }\end{array}$ & & & $21.24(36)$ \\
\hline
\end{tabular}




\section{Benthic metabolism}

Benthic habitat maps were used to select benthic metabolism sites that best represented the habitat within each estuary. A total of 11, 16, and 17 sites were sampled in triplicate over 4 seasons in the Hastings River ( $\mathrm{n}=132)$, Camden Haven $(\mathrm{n}=192)$, and Wallis Lake $(\mathrm{n}=204)$ estuaries, respectively, during field campaigns in July 2006 (winter), October 2006 (spring), February 2007 (summer), and April 2007 (autumn).

NP, GPP, and R were determined through a combination of in situ benthic chamber incubations and field laboratory-based sediment core incubations. Benthic chambers were used in habitats characterised by seagrass and/or large burrowing macrofauna, and cores were used in all other habitats. This methodology was employed to help minimise containment effects associated with the use of sediment cores in highly productive habitats (e.g. $\mathrm{O}_{2}$ bubble formation; Dalsgaard et al. 2000), while still enabling adequate replication of less productive habitats by using cores. Comparison of net production rates between triplicate cores and chambers incubated under a range of temperature and light conditions found no significant difference between the measured rates (data not shown). In addition, Eyre et al. (2011) recently found a good relationship between gross $\mathrm{O}_{2}$ productivity and gross $\mathrm{CO}_{2}$ fixation across a range of benthic habitats in shallow coastal systems using the same cores and chambers, demonstrating that there is no systematic bias in measured rates associated with using 2 types of incubation methods.

For core incubations, triplicate sediment cores were collected at each site with Plexiglass tubes (95 mm ID $\times 500 \mathrm{~mm}$ length) pushed approximately $200 \mathrm{~mm}$ into the sediment, leaving an overlying water volume of $\sim 1.9$ l. Cores were discarded if any surface disturbance of sediments was observed. At each site light attenuation was determined by measuring irradiance just above the water surface, just below the water surface, and at $1 \mathrm{~m}$ intervals to the sediment surface using a LiCor LI1400 light meter coupled to a 2 pi sensor, with kd values determined by the equations of Kirk (1977). Salinity, temperature, DO, turbidity, and $\mathrm{pH}$ were measured using a Quanta Hydrolab multiprobe. Uncapped sediment cores were placed in one of 4 large (150 1) perspex tanks filled with site water. Free exchange between the core and overlying water for $24 \mathrm{~h}$ allowed the cores to equilibrate and minimised any artefacts associated with disturbance of nutrient concentration profiles (Ferguson et al. 2004). Stirring was main- tained at a speed just below the resuspension threshold via rotating magnets throughout the equilibration and incubation periods. Light was delivered by 4 high-pressure $400 \mathrm{~W}$ sodium bulbs (Philips Son T Agro) with in situ light conditions emulated by shading individual cores to site-specific mean daily irradiance levels $( \pm 5 \%)$. After the initial $24 \mathrm{~h}$ equilibration period, cores were capped with gas-tight Plexiglass caps containing sampling ports for probe insertion, and input and output taps for drawing water samples. Water drawn from the cores was replaced through the input tap from a collapsible reserve water bag containing the site water used for the equilibration process, which was added to the reserve bags at the time of core capping, and therefore had the same initial baseline conditions as the cores. The cores were incubated over a $24 \mathrm{~h}$ diurnal cycle. The initial $12 \mathrm{~h}$ period was dark to minimise productivity underestimates that can result from nutrient depletion and bubble formation (Dalsgaard et al. 2000). Samples ( $30 \mathrm{ml})$ were collected from each core and the reserve water at $0,6,12,18$, and $24 \mathrm{~h}$ for alkalinity. Dissolved oxygen (DO) (Hach LDO optode DO Meter; $\pm 0.01 \mathrm{mg} \mathrm{l}^{-1}$ ), $\mathrm{pH}$, and temperature (Denver AP25 pH probe, $\pm 0.001 \mathrm{pH}$ units, $\pm 0.1^{\circ} \mathrm{C}$ ) were measured concurrently. The $\mathrm{pH}$ meter was calibrated prior to each time period. Samples for alkalinity were collected with a disposable syringe and filtered through $0.45 \mu \mathrm{m}$ syringe filters (Sartorious) into $10 \mathrm{ml}$ polypropylene vials, immediately stored at $4{ }^{\circ} \mathrm{C}$, and analysed within $3 \mathrm{wk}$ of collection. Alkalinity was determined by Gran titrations, and $\Sigma \mathrm{TCO}_{2}$ was determined from $\mathrm{pH}$, temperature, salinity, and alkalinity, assuming steady state (Stumm \& Morgan 1996) using the carbonic acid dissociation constants of Millero et al. (2006).

In situ diurnal incubations in macrophyte (i.e. seagrass meadows and macroalgae communities) and shallow subtidal/intertidal habitats colonised by burrowing macrofauna (predominantly the thalassinidean shrimp Trypaea australiensis) were done using benthic chambers of a similar design to those described by Webb \& Eyre (2004b). However, the chambers had a larger volume to surface area ratio (50 1:840 $\mathrm{cm}^{2}$ ) to reduce the artefacts associated with chamber incubations in highly productive habitats. Chambers were equilibrated for $\geq 24 \mathrm{~h}$ with the lids open, allowing free exchange of water with the water column. Chambers were then sealed at dusk and sampled for $\mathrm{O}_{2}, \mathrm{pH}$, temperature, and alkalinity (as per core incubations) at 6 time intervals over the $18 \mathrm{~h}$ incubation ( 0 h, 2 h, 4 h, dawn, dawn +3 h, and dawn $+\sim 6 \mathrm{~h}$ ) with the light period capturing solar noon. 


\section{Physical, chemical, and biological parameters}

At each site during each sampling campaign we also measured benthic phytopigment concentration (chlorophyll [chl] $a, b$, and $c$, and pheophytin), benthic total organic carbon (TOC), and total nitrogen (TN) concentration and stable isotope ratio and temperature (Table 3). Briefly, at the conclusion of the core incubations a section of the 0 to $5 \mathrm{~mm}$ depth of sediment was sampled for benthic pigments, and the top 0 to10 mm depth was sectioned for TOC and TN concentration and isotope ratio. Benthic pigment samples were placed into centrifuge vials containing $5 \mathrm{ml}$ of $90 \%$ acetone, wrapped in aluminium foil, and stored at $-20^{\circ} \mathrm{C}$ until analysis (within $3 \mathrm{wk}$ ). Samples for TOC and TN were placed in aluminium foil and frozen $\left(-20^{\circ} \mathrm{C}\right)$ until analysed. For chamber incubations, a sediment core was collected from within each chamber (95 mm i.d., $200 \mathrm{~mm}$ deep) and was sampled as per core incubations. Full details of analytical methods are presented in Maher \& Eyre (2010).

\section{Calculations}

Benthic flux rates of $\mathrm{O}_{2}$ and $\Sigma \mathrm{TCO}_{2}$ were calculated using the following equation (Ferguson et al. 2003):

$$
F=\left(\left[C_{t 1}-C_{t 0}\right] \times V / S A\right) / T
$$
where $F=$ flux rate $\left(\mu \mathrm{mol} \mathrm{m}{ }^{-2} \mathrm{~h}^{-1}\right) ; C_{t 1}=$ concentration of $\mathrm{O}_{2} / \Sigma \mathrm{TCO}_{2}$ at the end of the incubation period $\left(\mu \mathrm{mol} \mathrm{l}{ }^{-1}\right) ; C_{t 0}=$ the initial concentration of $\mathrm{O}_{2} / \Sigma \mathrm{TCO}_{2}$ $\left(\mu \mathrm{mol}{ }^{-1}\right) ; V=$ volume of overlying water $(1) ; S A=$ surface area of the core/chamber; and $T=$ incubation time. Concentrations of $\mathrm{O}_{2}$ and $\Sigma \mathrm{TCO}_{2}$ were corrected for the addition of replacement water during each sampling period. Benthic flux rates were corrected for the pelagic contribution in the core and chambers using site-specific volumetric pelagic GPP and R rates, and the site specific photosynthesis-irradiance (P-I) relationship (for GPP) (Maher \& Eyre unpubl.).

Benthic respiration (R) was calculated as the flux rate during the dark incubation period and gross benthic production (GPP) was calculated by adding dark flux rates $(\mathrm{R})$ to net light flux rates (net benthic productivity, NP), i.e. GPP $=\mathrm{NP}+\mathrm{R}$. Daily rates were derived for NP and GPP by multiplying hourly rates by photoperiod, and daily rates for $\mathrm{R}$ were derived by multiplying hourly rates by 24 . For statistical analysis and comparisons between metabolic rates based on $\mathrm{O}_{2}$ and $\Sigma \mathrm{TCO}_{2}$ fluxes, benthic metabolism rates based on $\mathrm{O}_{2}$ fluxes were converted to carbon equivalents using a photosynthetic quotient of 1 and a respiratory quotient of 1 (Kirk 1983, Hopkinson \& Smith 2005, Barrón et al. 2004, 2006).

Table 3. Physical, chemical, and biological parameters measured at each site during the study

\begin{tabular}{|c|c|c|c|c|}
\hline Parameter & Abbreviation & Method & Precision & Source \\
\hline Mean daily benthic light & Light & Li-Cor LI 1400 & $\pm 2 \%$ & \\
\hline Light attenuation & $\mathrm{kd}$ & Li-Cor LI 1400 & & Kirk (1977) \\
\hline Salinity & Salinity & Quanta Hydrolab multiprobe & $\pm 0.3 \mathrm{psu}$ & \\
\hline Distance from mouth & Dis & GPS + ArcMap GIS & $\pm 20 \mathrm{~m}$ & \\
\hline $\begin{array}{l}\text { Isotope ratios of sediment } \\
\text { organic carbon }\end{array}$ & $\mathrm{TO}^{13} \mathrm{C}$ & $\begin{array}{l}\text { Acid fuming (to remove inorganic carbon) } \\
\text { Flash EA coupled to Thermo Delta V+ IRMS }\end{array}$ & $\pm 0.1 \%$ & \\
\hline $\begin{array}{l}\text { Benthic organic carbon } \\
\text { concentration }\end{array}$ & TOC & $\begin{array}{l}\text { Acid fuming (to remove inorganic carbon) } \\
\text { Flash EA coupled to Thermo Delta V+ IRMS }\end{array}$ & $\pm 0.1 \%$ & \\
\hline Isotope ratios of sediment nitrogen & $\mathrm{T}^{15} \mathrm{~N}$ & Flash EA coupled to Thermo Delta V+ IRMS & $\pm 0.1 \%$ & \\
\hline Sediment nitrogen content & $\mathrm{TN}$ & Flash EA coupled to Thermo Delta V+ IRMS & $\pm 0.1 \%$ & \\
\hline Benthic pheophytin concentration & Pheo & $\begin{array}{l}90 \% \text { actetone extraction, analysed } \\
\text { spectrophotometrically }\end{array}$ & $4.1 \%$ & $\begin{array}{l}\text { Strickland \& Parsons } \\
(1972) ; \text { equations } \\
\text { from Jeffrey \& } \\
\text { Welschmeyer (1997) }\end{array}$ \\
\hline $\begin{array}{l}\text { Benthic chlorophyll } b \\
\text { concentration }\end{array}$ & $\mathrm{Chl} b$ & $\begin{array}{l}90 \% \text { actetone extraction, analysed } \\
\text { spectrophotometrically }\end{array}$ & $4.1 \%$ & $\begin{array}{l}\text { Strickland \& Parsons } \\
(1972) ; \text { equations } \\
\text { from Jeffrey \& } \\
\text { Welschmeyer (1997) }\end{array}$ \\
\hline $\begin{array}{l}\text { Benthic chlorophyll } C \\
\text { concentration }\end{array}$ & $\mathrm{Chl} C$ & $\begin{array}{l}90 \% \text { actetone extraction, analysed } \\
\text { spectrophotometrically }\end{array}$ & $4.1 \%$ & $\begin{array}{l}\text { Strickland \& Parsons } \\
(1972) ; \text { equations } \\
\text { from Jeffrey \& } \\
\text { Welschmeyer (1997) }\end{array}$ \\
\hline
\end{tabular}




\section{Benthic carbon budget}

Integrated, estuary-wide seasonal and annual benthic carbon budgets were constructed based on habitat-specific rates of GPP, NP, and $\mathrm{R}$, and calculated habitat area. The budgets are based on the $\Sigma \mathrm{TCO}_{2}$ fluxes to minimise any potential error introduced by inaccurate assumptions relating to photosynthesis and respiratory quotients (Anderson et al. 1986). Values are presented as tC $\mathrm{yr}^{-1}$ (annual budgets). As the estuaries vary in size and relative coverage of habits, the proportional contribution of each habitat to total estuarine benthic GPP and R is also presented.

Errors for each of the benthic carbon budget terms were calculated using the equation (Eyre 1995, Stutes et al. 2007):

$$
\begin{aligned}
& \text { Budget term error }=\left[\left(\text { mean }_{1} \times \text { error }_{2}\right)^{2}+\right. \\
& \left.\left(\text { mean }_{2} \times \text { error }_{1}\right)^{2}+\left(\text { error }_{1} \times \text { error }_{2}\right)^{2}\right]^{0.5}
\end{aligned}
$$

where the subscripts 1 and 2 represent the process (e.g. GPP) and the habitat area, respectively. The error of each of the benthic processes (GPP, R, NP) is defined as the standard error of replicate measurements within a habitat, and the error term for benthic habitat area was defined as $10 \%$ of calculated coverage (coverage values from Eyre \& Maher 2010).

\section{Statistical analysis}

Log transformation of data did not improve regression models; therefore non-transformed data was used in all models. Due to the differences between the likely drivers of benthic metabolism in macrophyte and non-macrophyte habitats, separate analysis, and modelling were performed by grouping habitats into 1 of these 2 classes. Pearson correlation coefficients were calculated to determine physicochemical and biological drivers of benthic metabolism. 2-way analyses of variance (ANOVA) were run for benthic metabolic parameters (GPP, R, and NP) to test for differences between habitats and seasons across the 3 estuaries. Where significant differences were found, Tukey's post hoc tests were used to determine homogenous subsets. All statistical analysis was undertaken using SPSS version 17.

\section{Modelling}

Benthic metabolism was modelled by stepwise multiple regression (SPSS version 17) and ANNs using a suite of physical and biological parameters that were collected during the study (Table 3). Stepwise multiple regression was carried out using the probability of $F$ criteria, with entry level set at $\alpha=$ 0.05 and removal set at $\alpha=0.1$

Feed-forward ANN with one layer of hidden nodes and one output variable (GPP, R, or P/R ratio) were implemented using JMP 7 software (SAS), which fits the model using standard nonlinear least-square regression techniques. Continuous data is scaled by the logistic function:

$$
S(x)=1 /\left(1+\mathrm{e}^{-\mathrm{x}}\right)
$$

transforming the data to have a mean of 0 and standard deviation of 1. Each hidden node is defined as (SAS 2007):

$$
H_{j}=S_{H}\left[c_{j}+\sum_{i=1}^{N_{X}}\left(a_{i j} X_{i}\right)\right]
$$

where $N_{X}$ is the number of x variables, $S_{H}(x)$ is the logistic function, $X_{i}$ are the inputs (scaled to be in the interval 0,1$)$. The outputs $\left(\widehat{Y}_{k}\right)$ are calculated as

$$
\widehat{Y}_{k}=S_{Y}\left[d_{k}+\sum_{j=1}^{N_{H}}\left(b_{j k} H_{j}\right)\right]
$$

where $N_{H}$ is the number of hidden nodes, $S_{Y}(x)$ is the identification function, and the coefficients $a, b, c$, and $d$ are to be estimated.

Variable selection was carried out by 3 methods. The first used the variables selected from stepwise multiple regression. The second used principle component analysis, with variables selected based on significant co-contribution with benthic metabolic parameters to principle components. The third method incorporated all variables (Table 3), as opposed to a smaller number of principal variables (e.g. Rochelle-Newall et al 2007) into the models due to the inherent difficulties in extracting the relative importance of individual variables to ANN structure (Millie et al 2006). Due to the influence initial weights have on ANN (Bishop 1995), 500 models were initiated for each combination of variables, and the number of hidden nodes was increased stepwise from 2 to 10 . Model validation was undertaken by the cross-validation method. Briefly, 30\% of the data was randomly selected and excluded from the training and testing phase of the model construction. The model was then applied to this 'holdout' data, and model performance was determined by the prediction accuracy of the cross validation ( $\mathrm{R}^{2}$ and $\left.\mathrm{RMSE}\right)$. 


\section{RESULTS}

\section{Gross primary production}

Seasonal GPP ranged from $\sim 0$ to $5400 \mathrm{mg} \mathrm{C} \mathrm{m}^{-2}$ $\mathrm{d}^{-1}$, with the highest GPP found in the Zostera habitats of the Hastings River during summer, while GPP in the Wallis Lake fluvial muds/sands and Hastings River marine channel habitats were the lowest and did not exceed $400 \mathrm{mg} \mathrm{C} \mathrm{m}^{-2} \mathrm{~d}^{-1}$ during the study. (Appendix 1). 2-way ANOVA based on $\mathrm{O}_{2}$ and $\mathrm{TCO}_{2}$ fluxes (with season and habitat as factors) indicated there were significantly differences between habitat types $\left(\mathrm{O}_{2} ; F_{11,528}=\right.$ 105.27, $\mathrm{p}<0.001$ and $\Sigma \mathrm{TCO}_{2 i} F_{11,528}=92.47, \mathrm{p}<$ $0.001)$ and seasons $\left(\mathrm{O}_{2} ; F_{3,528}=44.81, \mathrm{p}<0.001\right.$ and $\left.\Sigma \mathrm{TCO}_{2}: F_{3,528}=19.62, \mathrm{p}<0.001\right)$. Tukey's HSD tests revealed that GPP followed a seasonal trend with summer > spring, autumn > winter, and that macrophyte habitats (with the exception of Halophila) were significantly more productive than intertidal and Halophila habitats, which were significantly more productive than subtidal habitats (i.e. Zostera, Posidonia, Ruppia, macroalgae > Halophila, intertidal sands, intertidal muds > subtidal muds, subtidal sands, fluvial muds/sands, marine channel, depositional mud basin).

\section{Respiration}

Macrophyte habitats had the highest rates of $\mathrm{R}$, up to $\sim 6000 \mathrm{mg} \mathrm{C} \mathrm{m}^{-2} \mathrm{~d}^{-1}$ and the lowest rates were found in the Marine Channel habitats (Appendix 1). 2-way ANOVA based on both $\mathrm{O}_{2}$ and $\Sigma \mathrm{TCO}_{2}$ fluxes showed there were significant differences in $\mathrm{R}$ rates between habitats $\left(\mathrm{O}_{2 i} F_{11,528}=121.88, \mathrm{p}<\right.$ $\left.0.001, \Sigma \mathrm{TCO}_{2 i} F_{11,528}=70.02, \mathrm{p}<0.001\right)$ and seasons $\left(\mathrm{O}_{2} ; F_{3,528}=68.78, \mathrm{p}<0.001, \Sigma \mathrm{TCO}_{2} ; F_{3,528}=\right.$ 30.06, $\mathrm{p}<0.001$ ). Tukey's HSD post hoc analyses indicated that $\mathrm{R}$ followed the same habitat and seasonal trends as GPP, with $\mathrm{R}$ rates in macrophyte habitats higher than intertidal habitats, which were higher than subtidal and summer $>$ spring and autumn $>$ winter.

\section{Net production}

Net production ranged from negative (i.e. $\mathrm{R}>\mathrm{GPP}$ ) to positive (i.e. GPP > R) among the habitats (Appendix 1). Highest rates of autotrophy were recorded in Posidonia and Zostera habitats (up to 1200 mg C $\left.\mathrm{m}^{-2} \mathrm{~d}^{-1}\right)$, and the Macroalgae habitat during summer had the highest rates of heterotrophy (NP -1100 mg $\mathrm{C} \mathrm{m}^{-2} \mathrm{~d}^{-1}$ ). The seasonal trend exhibited in GPP and $\mathrm{R}$ rates was less pronounced for NP, although NP (based on $\mathrm{O}_{2}$ fluxes) was significantly lower during winter $\left(F_{3,528}=4.76, p=0.003\right)$. There was no significant effect of season on $\Sigma \mathrm{TCO}_{2} \mathrm{NP}$ rates $\left(F_{3,528}=\right.$ $0.160, p=0.923)$. There were significant differences in the NP of habitats $\left(\mathrm{O}_{2}: F_{11,528}=16.40, \mathrm{p}<0.001\right.$, $\left.\Sigma \mathrm{TCO}_{2}: F_{11,528}=14.567, \mathrm{p}<0.001\right)$, with Zostera, Posidonia > Halophila, Ruppia, intertidal mud, subtidal sand, subtidal mud $>$ marine channel, intertidal sand, fluvial muds/sands > depositional mud basin, macroalgae.

\section{Physico-chemical and biological drivers of benthic metabolism}

GPP rates in non-macrophyte habitats were driven by the interaction of organic matter supply (TOC and TN concentrations), physico-chemical properties (light, salinity, distance from estuary mouth), and benthic microalgae biomass (chl $a$ and $\mathrm{chl} c$ ) (Table 4). In macrophyte habitats, GPP was also coupled to the physico-chemical properties of the habitat (light, salinity, and temperature), but organic matter supply and benthic algae biomass were not significant factors. $\mathrm{R}$ in non-macrophyte communities was correlated to most of the variables measured; only chl $b$, TOC and $\mathrm{TO}^{13} \mathrm{C}$ and TN were not correlated to either $\mathrm{O}_{2}$ or $\mathrm{TCO}_{2}$ estimates of $\mathrm{R}$ (Table 4). In macrophyte habitats, R was correlated to light, temperature, $\mathrm{TO}^{13} \mathrm{C}, \mathrm{TN}, \mathrm{Kd}$, and salinity. NP in nonmacrophyte habitats was correlated to most of the variables measured with the highest correlation coefficients for light, chl $a$, and chl $c$. In macrophyte habitats, NP was correlated to temperature, pheophytin and chl $a$, salinity, distance, and $\mathrm{TN}$ and $\mathrm{TO}^{13} \mathrm{C}$ (Table 4).

\section{Benthic carbon budgets}

Annual benthic carbon budgets based on habitatspecific seasonal rates of GPP, R, and NP (calculated from $\Sigma \mathrm{TCO}_{2}$ fluxes), and habitat area (Eyre \& Maher 2010) for each estuary are presented in Table 5. Zostera habitats in each estuary contributed the most to ecosystem benthic gross productivity, ranging from $37 \%$ in the Camden Haven to $51 \%$ in Wallis Lake. Other habitats that has substantial contributions to benthic gross production 


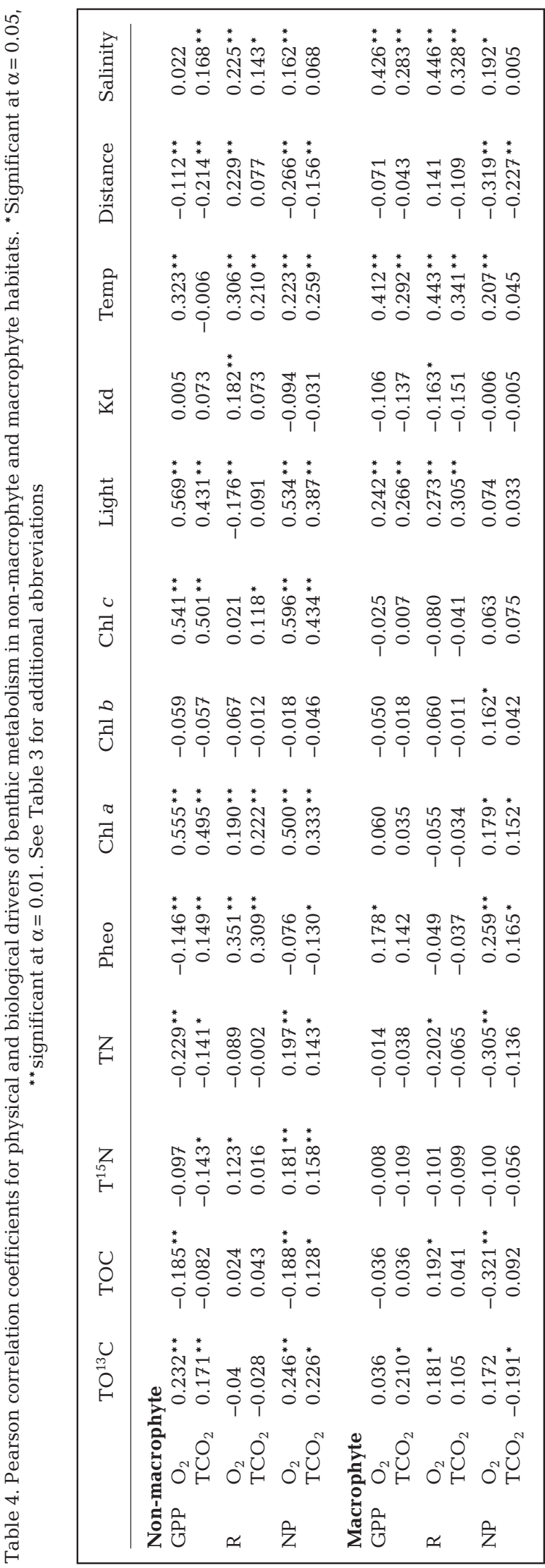

were subtidal sands and intertidal sands (Hastings River); Halophila, subtidal mud, and Ruppia (Camden Haven); and subtidal sands, Halophila, and Posidonia (Wallis Lake). Zostera habitats also contributed significantly to ecosystem-wide benthic R (34 to $44 \%$ ), along with intertidal sands, fluvial muds/sands, and marine channel (Hastings River); Halophila, subtidal mud, and Ruppia (Camden Haven); and Halophila and Posidonia (Wallis Lake). With the exception of Ruppia habitats in Wallis Lake, all seagrass habitats were net autotrophic over an annual basis. Benthic respiration exceeded carbon fixation in the Hastings River annually (NP $=-468 \mathrm{tC}$ or $-25 \mathrm{~g} \mathrm{C} \mathrm{m}^{-2} \mathrm{yr}^{-1}$ ), and the benthos in the Camden Haven (NP $=2733 \mathrm{tC}$ or $91 \mathrm{~g} \mathrm{C} \mathrm{m}^{-2}$ $\mathrm{yr}^{-1}$ ) and Wallis Lake (NP $=4981 \mathrm{tC}$ or $55 \mathrm{~g} \mathrm{C} \mathrm{m}^{-2}$ $\mathrm{yr}^{-1}$ ) estuaries was autotrophic over the study period (Table 5).

\section{Benthic metabolism models}

Results from stepwise multiple regressions are presented in Table 6. Model accuracy varied between $\mathrm{O}_{2}$ and $\mathrm{TCO}_{2}$ estimates of GPP, R, and NP, and between macrophyte and non-macrophyte habitats. Multiple regression models performed better for non-macrophyte habitats and for estimates of GPP, R, and NP based on $\mathrm{O}_{2}$ fluxes.

ANN models out-performed stepwise multiple regression, with benthic metabolism best modelled using all input parameters (Appendix 2). As with stepwise regression, models performed best for nonmacrophyte habitats, using $\mathrm{O}_{2}$ flux data. The architecture of the models (i.e. the number of hidden nodes) varied from 3 to 10, and RMSE from 44 to $1023 \mathrm{mg} \mathrm{C} \mathrm{m}^{-2} \mathrm{~d}^{-1}$.

Fig. 2 shows a comparison of prediction accuracy for ANN and stepwise multiple regression methods, using RMSE as a proxy for model accuracy along with modelled GPP in non-macrophyte habitats using stepwise multiple regression and ANN (using all variables). ANN clearly modelled benthic metabolism in macrophyte and non-macrophyte habitats better than linear regression methods using the variables measured during this study. Fig. 2E,F compare model outputs for GPP (based on $\mathrm{O}_{2}$ fluxes) in non-macrophyte habitats using stepwise regression and ANN. The ANN model predicted GPP extremely well across the range of observed values based on all input variables, while the accuracy of the stepwise regression model decreased at higher GPP rates. 
Table 5. Benthic carbon budget for three study estuaries. Values in parenthesis are propagated errors. See Table 2 for abbreviations

\begin{tabular}{|c|c|c|c|c|c|}
\hline $\begin{array}{l}\text { Habitat } \\
\text { type }\end{array}$ & $\begin{array}{l}\text { Gross pro- } \\
\text { duction (tC) }\end{array}$ & $\begin{array}{l}\% \text { of } \\
\text { total }\end{array}$ & $\begin{array}{l}\text { Respiration } \\
(\mathrm{tC})\end{array}$ & $\begin{array}{l}\% \text { of } \\
\text { total }\end{array}$ & $\begin{array}{c}\text { Net pro- } \\
\text { duction }(\mathrm{tC})\end{array}$ \\
\hline \multicolumn{6}{|l|}{ Hastings River } \\
\hline IS & $470(115)$ & 15 & 698 (135) & 19 & $-228(103)$ \\
\hline SS & $434(66)$ & 14 & $256(42)$ & 7 & $178(42)$ \\
\hline $\mathrm{Z}$ & $1422(101)$ & 46 & $1294(178)$ & 36 & 129 (145) \\
\hline $\mathrm{H}$ & $91(26)$ & 3 & $73(14)$ & 2 & $18(17)$ \\
\hline SM & $230(51)$ & 5 & 251 (53) & 7 & $-21(43)$ \\
\hline FMS & $311(47)$ & 10 & $450(71)$ & 12 & $-139(46)$ \\
\hline IM & $19(3)$ & 1 & $14(4)$ & 0 & $5(3)$ \\
\hline $\mathrm{MC}$ & $141(38)$ & 5 & 549 (98) & 16 & $-408(61)$ \\
\hline Total & $3118(548)$ & & 3586 (596) & & $-468(460)$ \\
\hline Total $\left(\mathrm{g} \mathrm{C} \mathrm{m}^{-2} \mathrm{yr}^{-1}\right)$ & ) $164(29)$ & & $189(31)$ & & $-25(24)$ \\
\hline \multicolumn{6}{|l|}{ Camden Haven } \\
\hline IS & $573(105)$ & 5 & $501(100)$ & 5 & $71(83)$ \\
\hline SS & $430(84)$ & 4 & 431 (108) & 5 & $-1(80)$ \\
\hline $\mathrm{Z}$ & $4413(855)$ & 37 & 3169 (568) & 34 & $1244(544)$ \\
\hline $\mathrm{H}$ & $1845(566)$ & 16 & 1174 (529) & 13 & $671(496)$ \\
\hline SM & $1817(221)$ & 15 & 1309 (169) & 14 & $508(146)$ \\
\hline FMS & $244(34)$ & 2 & $213(44)$ & 2 & $31(28)$ \\
\hline IM & 772 (129) & 6 & 711 (127) & 8 & $61(98)$ \\
\hline $\mathrm{MC}$ & $169(25)$ & 1 & $180(38)$ & 2 & $-10(26)$ \\
\hline $\mathrm{R}$ & $1672(220)$ & 14 & $1514(252)$ & 16 & $158(175)$ \\
\hline Total & 11935 (2239) & & 9202 (1934) & & 2733 (1678) \\
\hline Total $\left(\mathrm{g} \mathrm{C} \mathrm{m}^{-2}\right)$ & $398(75)$ & & $307(64)$ & & $91(55)$ \\
\hline \multicolumn{6}{|l|}{ Wallis Lake } \\
\hline IS & 434 (92) & 1 & $427(75)$ & 1 & $7(65)$ \\
\hline SS & 3155 (622) & 10 & 1399 (331) & 5 & 1756 (375) \\
\hline $\mathrm{Z}$ & 17196 (3759) & 51 & $12578(2148)$ & 44 & 4617 (2616) \\
\hline $\mathrm{H}$ & 3727 (508) & 11 & $3726(507)$ & 13 & $1(377)$ \\
\hline SM & $611(138)$ & 2 & $590(146)$ & 2 & $21(112)$ \\
\hline FMS & $1230(184)$ & 4 & $2128(296)$ & 7 & -899 (179) \\
\hline IM & $162(25)$ & 0 & $125(30)$ & 0 & $37(21)$ \\
\hline $\mathrm{MC}$ & 141 (29) & 0 & $95(22)$ & 0 & $46(24)$ \\
\hline $\mathrm{R}$ & 824 (153) & 2 & 903 (174) & 3 & $-79(127)$ \\
\hline $\mathrm{P}$ & $4866(647)$ & 14 & 4162 (583) & 14 & 704 (448) \\
\hline DMB & 904 (226) & 3 & 1968 (372) & 7 & $-1065(269)$ \\
\hline MA & $508(80)$ & 2 & $674(132)$ & 2 & $-166(91)$ \\
\hline Total & 33757 (6462) & & 28776 (4816) & & 4981 (4703) \\
\hline Total $\left(\mathrm{gC} \mathrm{m}^{-2}\right)$ & $375(72)$ & & $320(54)$ & & $55(52)$ \\
\hline
\end{tabular}

\section{DISCUSSION}

\section{Methodological considerations}

The true values of habitat-specific metabolic rates may vary from those presented here for several reasons. Containment effects associated with isolating the benthic community from in situ nutrient flux pathways may lead to an underestimate of metabolic rates due to resource limitation (Kemp \& Boynton 1980). Incubations in intertidal habitats were carried out under immersed conditions, which may underestimate metabolic rates which have been found to be higher under air-exposed conditions (Gribsholt \& Kristensen 2003). Respiration (and therefore GPP) rates may also be a minimal estimates as they were calculated from dark fluxes, and light-enhanced areal respiration has been documented in phototrophic benthic communities (Epping \& Jørgensen 1996). In spite of these potential limitations, the results obtained during this study fall within the range of published estuarine benthic metabolic rates (see below). Further, the degree of spatial and temporal replication and the use of commonly employed methodology (i.e. $\mathrm{O}_{2}$ and $\Sigma \mathrm{TCO}_{2}$ fluxes in benthic cores and chambers) enables a comparison of the importance of individual habitats within each of the studied estuaries and a comparison to previous studies, which typically employ the same methodology.

The $\Sigma \mathrm{TCO}_{2}$ fluxes reflect both organic matter mineralisation and carbonate dissolution and precipitation. To estimate the relative contribution of calcium carbonate $\left(\mathrm{CaCO}_{3}\right)$ precipitation and dissolution to our estimates of organic matter production and respiration we corrected our NP estimates for the maximum contribution of $\mathrm{CaCO}_{3}$ metabolism using the formula (Eyre \& Ferguson 2002)

$$
\Sigma \mathrm{TCO}_{2}{ }^{*}=\Sigma \mathrm{TCO}_{2}-0.5 \mathrm{TAlk}
$$

where $\mathrm{\Sigma TCO}_{2}{ }^{*}$ is the net $\Sigma \mathrm{TCO}_{2}$ flux associated with organic matter production and mineralization $(\mathrm{mmol} \mathrm{C}$ $\left.\mathrm{m}^{-2} \mathrm{~d}^{-1}\right), \Sigma \mathrm{TCO}_{2}$ is the net $\Sigma \mathrm{TCO}_{2}$ flux $\left(\mathrm{mmol} \mathrm{C} \mathrm{m} \mathrm{C}^{-2} \mathrm{~d}^{-1}\right)$ and TAlk is the net alkalinity flux (meq $\mathrm{m}^{-2} \mathrm{~d}^{-1}$; calculated by the same method used for $\Sigma \mathrm{TCO}_{2}$ and $\mathrm{O}_{2}$ fluxes). This correction represents a maximum potential contribution of $\mathrm{CaCO}_{3}$ to the $\Sigma \mathrm{TCO}_{2}$ fluxes, as anaerobic mineralization processes (e.g. sulphate reduction) also produce alkalinity (Anderson et al. 1986, Berelson et al. 1996, 1998, Eyre \& Ferguson 2002) A plot of net $\Sigma \mathrm{TCO}_{2}{ }^{*}$ versus net $\Sigma \mathrm{TCO}_{2}$ fluxes (Fig. 3) shows that $\mathrm{CaCO}_{3}$ dissolution and precipitation was a relatively minor process in the study estuaries with the average contribution of carbonate metabolism to the net $\Sigma \mathrm{TCO}_{2}$ of $\sim 10 \%$. Previous studies have shown that the magnitude of $\mathrm{CaCO}_{3}$ metabolism can be significant. For example, Barrón et al (2006) found that the $\mathrm{CO}_{2}$ flux from calcium carbonate production was equivalent to 
Table 6 . Results for best models calculated by stepwise multiple regression, using the probability of $F$ criteria, with entry level set at $\alpha=0.05$ and removal set at $\alpha=0.1$. See Tables $2 \& 3$ for additional abbreviations

\begin{tabular}{|c|c|c|c|c|c|c|c|}
\hline & $\mathrm{R}$ & R square & $\begin{array}{l}\text { Adjusted } \\
\text { R square }\end{array}$ & $\begin{array}{c}\text { RMSE } \\
\left(\mathrm{mgC} \mathrm{d}^{-1}\right)\end{array}$ & $F$ & Sig & Variables \\
\hline \multicolumn{8}{|c|}{ Non-macrophyte } \\
\hline $\mathrm{GPP}\left(\mathrm{O}_{2}\right)$ & 0.793 & 0.629 & 0.622 & 228 & 84.76 & $<0.001$ & Chl $c$, light, kd, chl $b$, temp \\
\hline GPP $\left(\mathrm{TCO}_{2}\right)$ & 0.739 & 0.545 & 0.536 & 234 & 60.00 & $<0.001$ & Chl c, light, kd, salinity, chl $b$ \\
\hline $\mathrm{R}\left(\mathrm{O}_{2}\right)$ & 0.607 & 0.369 & 0.358 & 147 & 36.63 & $<0.001$ & Pheo, temp, salinity, chl $b$ \\
\hline $\mathrm{R}\left(\mathrm{TCO}_{2}\right)$ & 0.428 & 0.183 & 0.170 & 230 & 14.08 & $<0.001$ & Pheo, salinity, kd, chl a \\
\hline $\mathrm{NP}\left(\mathrm{O}_{2}\right)$ & 0.765 & 0.585 & 0.575 & 217 & 58.41 & $<0.001$ & Chl $c$, light, pheo, chl $b$, kd, salinity \\
\hline $\mathrm{NP}\left(\mathrm{TCO}_{2}\right)$ & 0.644 & 0.414 & 0.403 & 253 & 35.40 & $<0.001$ & Chl $c$, light, pheo, $\mathrm{kd}$, chl $b$ \\
\hline \multicolumn{8}{|l|}{ Macrophyte } \\
\hline $\operatorname{GPP}\left(\mathrm{O}_{2}\right)$ & 0.529 & 0.280 & 0.268 & 1480 & 22.73 & $<0.001$ & Temp, salinity \\
\hline GPP $\left(\mathrm{TCO}_{2}\right)$ & 0.474 & 0.225 & 0.205 & 1291 & 11.23 & $<0.001$ & Temp, light, pheo, \\
\hline $\mathrm{R}\left(\mathrm{O}_{2}\right)$ & 0.594 & 0.353 & 0.324 & 1145 & 12.42 & $<0.001$ & Salinity, temp, dis, light, pheo \\
\hline $\mathrm{R}\left(\mathrm{TCO}_{2}\right)$ & 0.479 & 0.230 & 0.210 & 1283 & 11.53 & $<0.001$ & Light, temp, salinity \\
\hline $\mathrm{NP}\left(\mathrm{O}_{2}\right)$ & 0.430 & 0.185 & 0.164 & 790 & 8.77 & $<0.001$ & Temp, dis, kd \\
\hline $\mathrm{NP}\left(\mathrm{TCO}_{2}\right)$ & 0.467 & 0.218 & 0.191 & 753 & 8.01 & $<0.001$ & Dis, $\mathrm{TO}^{13} \mathrm{C}, \mathrm{T}^{15} \mathrm{~N}$, light \\
\hline
\end{tabular}

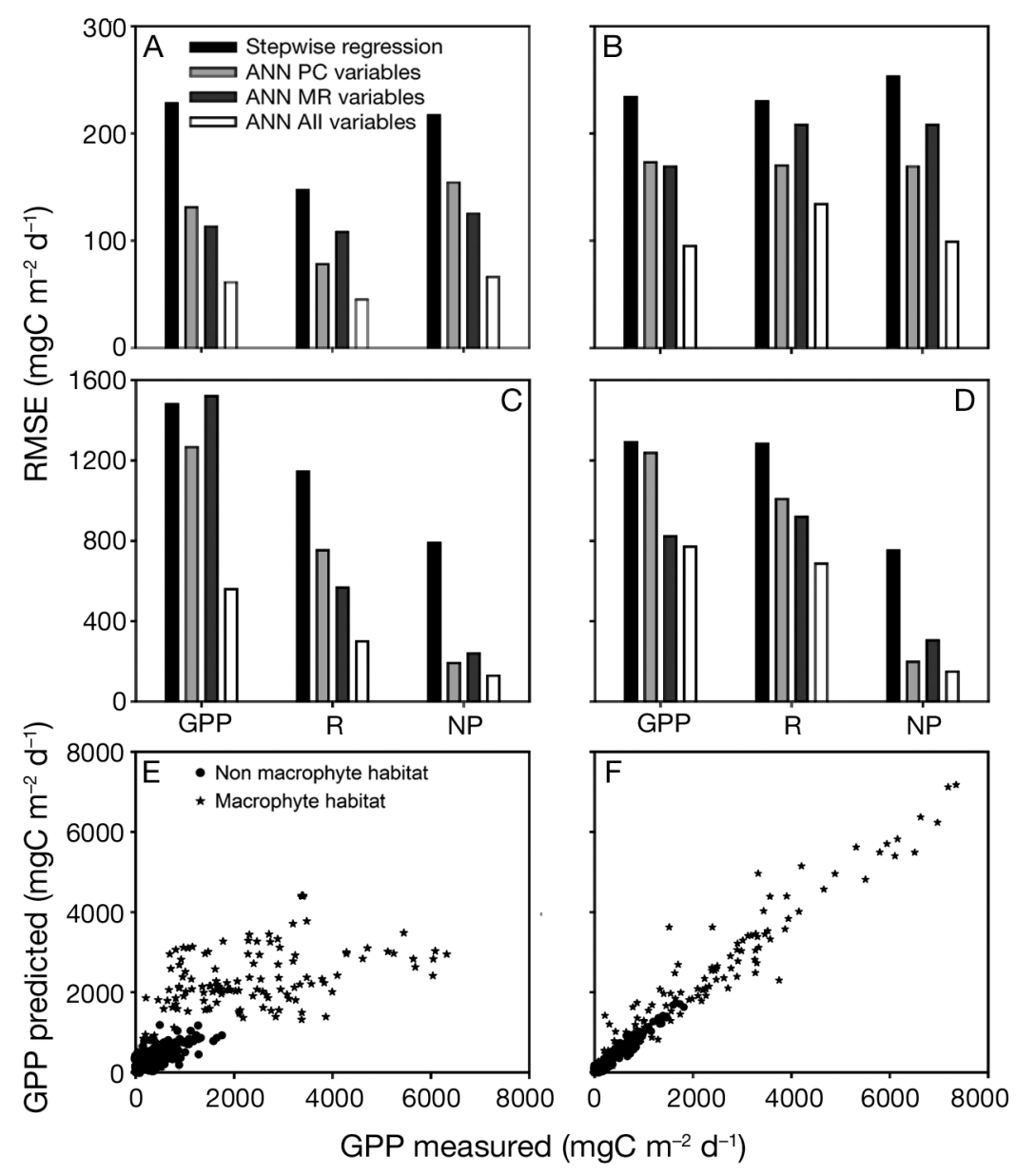

Fig. 2. Comparison of stepwise regression and ANN model performance for (A) $\mathrm{O}_{2}$ fluxes in non-macrophyte habitats, (B) $\Sigma \mathrm{TCO}_{2}$ fluxes in nonmacrophyte habitats, (C) $\mathrm{O}_{2}$ fluxes in macrophyte habitats, and (D) $\Sigma \mathrm{TCO}_{2}$ fluxes in macrophyte habitats. (E) Predicted versus observed model outputs for GPP using stepwise regression. (F) Predicted versus observed model outputs for GPP using ANN (with all input variables including training and validation data) $\sim 50 \%$ the net community production in a Posidonia oceanica meadow, and $\mathrm{CO}_{2}$ uptake due to $\mathrm{CaCO}_{3}$ dissolution was similar to the release of $\mathrm{CO}_{2}$ by NP in unvegetated sediments. It should be noted that the study by Barrón et al (2006) was undertaken in carbonate rich sediments (>90\% $\left.\mathrm{CaCO}_{3}\right)$. In contrast, Eyre et al (2011) found a strong correlation between annual GPP based on $\Sigma \mathrm{TCO}_{2}$ and $\mathrm{O}_{2}$ fluxes, with a photosynthetic quotient of 1.25 , and concluded there was minimal calcium carbonate precipitation associated with autotrophic production in the subtropical southern Moreton Bay estuary.

\section{Habitat-specific and system-wide benthic metabolism}

Quantification of seasonal rates of metabolism for each of the 12 identified benthic habitat types reiterates the well-established view that estuarine ecosystems are highly productive. Integrated, system-wide annual benthic gross carbon fixation rates for the 3 study estuaries were 164 to $398 \mathrm{~g} \mathrm{C}$ $\mathrm{m}^{-2} \mathrm{yr}^{-1}$; benthic respiration ranged from 189 to $320 \mathrm{~g} \mathrm{C} \mathrm{m}^{-2} \mathrm{yr}^{-1}$; and net benthic production ranged from net heterotrophy $\left(-25 \pm 24 \mathrm{~g} \mathrm{C} \mathrm{m}^{-2} \mathrm{yr}^{-1}\right.$ in the Hastings River) to net autotrophy 


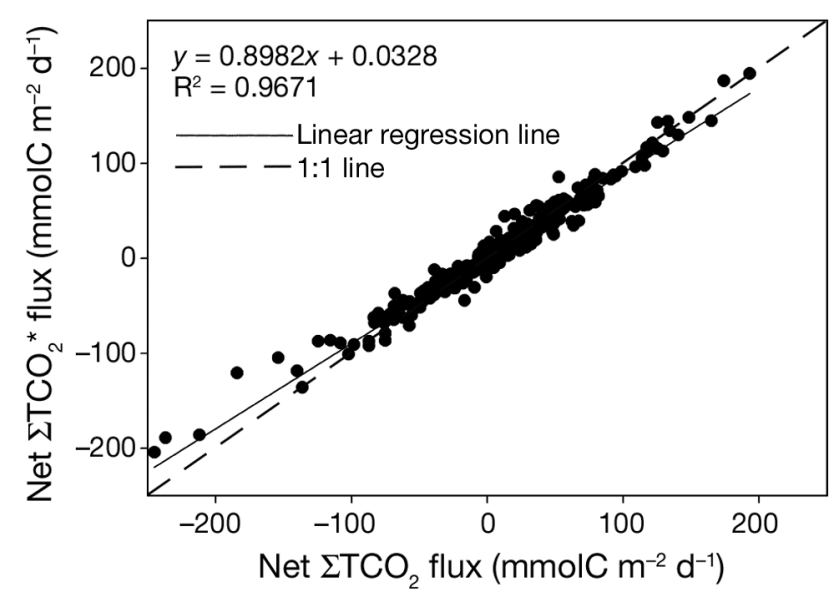

Fig. 3. Comparison between net $\Sigma \mathrm{TCO}_{2}$ fluxes and net $\Sigma \mathrm{TCO}_{2}$ fluxes corrected for the maximum contribution of calcium carbonate precipitation and dissolution (net $\Sigma \mathrm{TCO}_{2}{ }^{*}$ fluxes)

(55 $\pm 52 \mathrm{~g} \mathrm{C} \mathrm{m}^{-2} \mathrm{yr}^{-1}$ in Wallis Lake and $91 \pm 55 \mathrm{~g} \mathrm{C}$ $\mathrm{m}^{-2} \mathrm{yr}^{-1}$ in Camden Haven; Table 5).

Estuary-wide benthic GPP rates were higher than those compiled for European estuaries (97 to $166 \mathrm{~g} \mathrm{C}$ $\mathrm{m}^{-2} \mathrm{yr}^{-1}$; Gazeau et al. 2004 and references therein) but comparable to other seagrass-dominated systems. For example, Ziegler \& Benner (1999) estimated gross benthic production of Laguna Madre to be $684 \mathrm{~g} \mathrm{C} \mathrm{m}^{-2} \mathrm{yr}^{-1}$, and benthic GPP in San Quintin Bay was estimated to be $499 \mathrm{~g} \mathrm{C} \mathrm{m}^{-2} \mathrm{yr}^{-1}$ (IbarraObando et al. 2004). In a cross-system comparison ( $\mathrm{n}=141)$, Duarte et al. (2010) found that mean seagrass community GPP was $985 \mathrm{~g} \mathrm{C} \mathrm{m}^{-2} \mathrm{yr}^{-1}$ (daily rates $\times 365)$. Estuarine benthic respiration rates range from 13 to $504 \mathrm{~g} \mathrm{C} \mathrm{m}^{-2} \mathrm{yr}^{-1}$ (mean $149 \mathrm{~g} \mathrm{C} \mathrm{m}^{-2}$ $\mathrm{yr}^{-1}$; Hopkinson \& Smith 2005 and references therein), with the highest values associated with systems with large inputs of seagrass and saltmarsh organic matter. Further, Duarte et al. 2010 found that the mean $\mathrm{R}$ rate of seagrass communities was $\sim 819 \mathrm{~g}$ $\mathrm{C} \mathrm{m} \mathrm{m}^{-2} \mathrm{yr}^{-1}$ in a cross-system analysis; therefore the higher-than-average values found in the present study likely represent a similar high input of seagrass organic matter and significant contribution of seagrasses to benthic habitats (Table 2). The benthic NP for European estuaries (from Gazeau et al. 2004) ranged from -187 to $16 \mathrm{~g} \mathrm{C} \mathrm{m}^{-2} \mathrm{yr}^{-1}$ (mean $-63 \mathrm{~g} \mathrm{C}$ $\left.\mathrm{m}^{-2} \mathrm{yr}^{-1}\right)$, similar to the system-wide value obtained for the Hastings River. The Camden Haven and Wallis Lake estuaries had higher rates of net carbon fixation, $\sim 55$ to $100 \mathrm{~g} \mathrm{C} \mathrm{m}^{-2} \mathrm{yr}^{-1}$, which were similar to values obtained for seagrass-dominated systems previously (Ziegler \& Benner 1999, Kaldy et al. 2002, Santos et al. 2004, Stutes et al. 2007) and similar to the mean value obtained by Duarte et al. (2010) for seagrass community $\mathrm{NP}\left(\sim 120 \mathrm{~g} \mathrm{C} \mathrm{m}^{-2} \mathrm{yr}^{-1}\right)$.

While the rates of estuary-wide benthic GPP, $\mathrm{R}$, and NP from the present study generally fall within the range from previous studies, there is a paucity of data from some habitats, and few studies have estimated the relative contribution of different habitats to estuary-wide benthic metabolism. Seagrass habitats contributed significantly to estuary-wide benthic GPP, R, and NP (Table 5). Interestingly, in the Hastings River estuary, seagrass (Zostera and Halophila habitats) only covered $\sim 8 \%$ of the benthos, yet contributed $49 \%$ of system benthic GPP. Seagrass habitats in Camden Haven and Wallis Lake covered a similar proportion of the benthos $(\sim 38 \%)$ and contributed 67 and $78 \%$ of estuarine benthic GPP, respectively. Seagrass habitats in all estuaries were also areas of intense benthic respiration, contributing 38,63 , and $74 \%$ of system-wide benthic $\mathrm{R}$ in the Hastings River, Camden Haven, and Wallis Lake estuaries, respectively. Subtidal shoal habitats (subtidal mud and subtidal sand) along with seagrass habitats were areas of significant NP. The NP of subtidal sand in the Hastings River exceeded net production of seagrass habitats, and subtidal mud and subtidal sand habitats contributed $\sim 18 \%$ of ecosystem benthic NP in Camden Haven and Wallis Lake. A large contribution of seagrass habitats to ecosystem benthic metabolism has been reported in previous studies. For example Ibarra-Obando et al. (2004) found that seagrass beds dominated estuarine benthic primary production and respiration $(\sim 80 \%)$ and covered $40 \%$ of the estuary area. Further, seagrass habitats in southern Moreton Bay only cover $13 \%$ of the area yet contribute $\sim 50 \%$ of the annual open water estuarine production (Eyre et al. 2011).

\section{Factors driving benthic metabolism}

Macrophyte habitats

Temperature and light were the main variables driving GPP and R in seagrass communities. Both temperature and light have been found to be significant factors controlling seagrass photosynthesis, growth, and respiration (Marsh et al. 1986, Lee et al. 2007). Interestingly, both light and temperature conditions during the study were within the 'optimal' range for temperate seagrass growth (Lee et al. 2007 and references therein), indicating that macrophyte habitat metabolism may be driven mainly by the nonmacrophyte components. Further evidence of this is 
the correlation between NP rates and benthic pheophytin and chl a concentrations (Table 4), indicating live and senescent microalgae influence NP. Several studies have also highlighted the importance of epiphytes and benthic microalgae to seagrass habitat productivity; for example, 20 to $60 \%$ of benthic production is associated with epiphytes in macrophyte habitats (Moncreiff et al. 1992, Heip et al. 1995, Hemminga \& Duarte 2000), and 20 to $35 \%$ of habitat productivity has been attributed to benthic microalgae (Moncreiff et al. 1992, Eyre et al. 2011).

In addition to temperature and light, the source of benthic organic matter $\left(\mathrm{TO}^{13} \mathrm{C}, \mathrm{T}^{15} \mathrm{~N}\right)$ but not the quantity (TOC, TN) had an influence of $\mathrm{R}$ in macrophyte habitats (Table 4). Macrophyte habitats can effectively trap sestonic particles due to flow attenuation within the canopy, and trapping efficiency has been found to be inversely proportional to seston concentration in the overlying water (Duarte et al. 1999). Therefore the organic matter within these habitats is composed of autochthonous (macrophyte and microalgae) and allochthonous (deposited seston) material (Papadimitriou et al. 2005) creating a complex mix of labile and refractory substrates (Hemminga \& Duarte 2000).

\section{Non-macrophyte habitats}

Temperature, light, and algal biomass are wellestablished factors influencing benthic productivity in non-macrophyte habitats (MacIntyre et al. 1996, Cahoon 1999, Underwood \& Kromkamp 1999). Up to $60 \%$ of the variability in productivity of benthic microalgae can be explained by a combination of light and biomass (Pinckney \& Zingmark 1993). In the present study, both light and biomass explained $\sim 25 \%$ of the observed variability in non-macrophyte habitat GPP and NP rates (Table 4), and temperature and organic matter composition explained $\sim 20 \%$ of the observed GPP and NP. A combination of light, temperature, and benthic algae biomass explained up to $60 \%$ of the observed variability in GPP and NP (Table 6). The results suggest that the main factors influencing GPP and NP in non-macrophyte habitats were measured during the present study, and benthic productivity in the non-macrophyte habitats of the study estuaries is controlled by the same factors previously documented.

Hopkinson \& Smith (2005) found that organic matter supply and temperature best explained benthic respiration in a cross-system analysis; however, the 2 factors can operate on different annual cycles, thus complicating the observed relationships. For example, organic matter supply to the benthos may be highest during phytoplankton blooms, or during moderate rainfall events, while temperature generally follows a predictable seasonal pattern. During the present study, respiration rates were also most tightly coupled to organic matter supply and composition, and temperature; however, the relationships were not as strong as for GPP and NP (Table 4). Pelagic chl a concentrations where highest during summer and autumn; however, freshwater inflow (and therefore allochthonous organic matter supply) exhibited sporadic fluctuations associated with rainfall events, and was highest during spring (D. Maher unpubl. data). Seasonal changes in the composition (allochthonous versus autochthonous) and supply of organic matter to the benthos, along with seasonal temperature changes, likely drive benthic $\mathrm{R}$ in the studied estuaries; however, further research is clearly needed to determine relative importance of each of these variables.

Applicability of ANNs to benthic metabolism

Stepwise regression has been the most commonly used method for modelling ecological systems; however, there is an increasing interest in the use of ANNs. ANNs have several benefits over traditional statistical modelling techniques, which make them well-suited to modelling ecological systems. ANNs require no a priori model determination (e.g. linear versus non-linear relationships) and are well suited to process multidimensional data, particularly when non-linear relationships exist between parameters (Rochelle-Newall et al. 2007). Several studies have successfully used ANNs to model phytoplankton production (Whitehead et al. 1997, Barciela et al. 1999, Scardi \& Harding 1999) and pelagic community metabolism (Rochelle-Newall et al. 2007); however, to our knowledge no study has looked at the potential for using ANNs to model benthic metabolism. The present study clearly shows that ANNs can successfully be used to model benthic metabolism based on a suite of easily measure parameters. Further, ANNs outperformed stepwise regression for all benthic metabolic process for seagrass and non-seagrass communities using both $\mathrm{O}_{2}$ and $\mathrm{TCO}_{2}$ fluxes (Table 6, Fig. 2, Appendix 2).

Both stepwise regression and ANN models performed better for non-macrophyte habitats. While most of the variables generally associated with benthic metabolism in non-macrophyte habitats (i.e. light, 
temp, and benthic microalgae biomass) were measured, some key factors that may influence productivity and respiration in macrophyte habitats were not measured. For example, seagrass morphology (Duarte 1991), time since colonization (Barrón et al. 2004), flow velocity (Enríquez \& Rodríguez-Román 2006, Peralta et al. 2006), and nutrient concentrations (Hemminga et al. 1991, Lee et al. 2007, Kowalski et al. 2009) have all been found to significantly influence seagrass habitat metabolism. Coupled with this is a smaller sample size for macrophyte $(\mathrm{n}=150)$ versus non-macrophyte $(\mathrm{n}=$ 379) habitats. Despite the potential lack of all the appropriate input variables, ANNs explained 65 to $88 \%$ (based on cross-validation) of the observed variability of benthic metabolic rates in macrophytes.

The ANN models were used to predict habitat specific and system-wide NP changes associated with a $1^{\circ} \mathrm{C}$ and $2^{\circ} \mathrm{C}$ increase (Fig. 4). As ANNs are typically inaccurate at predicting outside the bounds of the input data (Flood \& Kartam 1994, Minns \& Hall 1996, Maier \& Dandy 2000), forecast models were bound by the maximum values of input data. Therefore model predictions were bound by the highest recorded temperature during the study $\left(\sim 27^{\circ} \mathrm{C}\right)$. This precluded the inclusion of NP rates for several sites during summer only; however, model outputs were still available for all habitat types in each of the systems.

The model results indicate that NP will increase in autotrophic habitats, and NP will decrease in heterotrophic habitats associated with temperature increases. Both system-wide GPP and R modelled under a similar $1^{\circ} \mathrm{C}$ and $2^{\circ} \mathrm{C}$ increase were higher than observed, but on a system wide basis the increases in GPP outweighed those in $\mathrm{R}$, therefore estuary-wide benthic NP is predicted to increase. The greatest changes were observed in the most productive habitats (mainly macrophyte habitats). The model results suggest that in the Hastings River, benthic metabolism may become balanced rather than heterotrophic, and net carbon fixation may increase up to $40 \%$ in the other systems.

Net carbon fixation by the benthos is either exported or buried within the system (Duarte et al. 2005). Seagrass communities export $24 \%$ of net carbon fixation while $16 \%$ is buried (Duarte \& Cebrian 1996). As the predicted increases in net carbon fixation occur mainly in seagrass habitats, temperature increases may actually increase carbon burial rates in macrophyte-dominated systems. The role of temperature changes in system-wide carbon burial within estuaries has, to our knowledge, not been fully explored, and further research is clearly required to adequately constrain global carbon models.

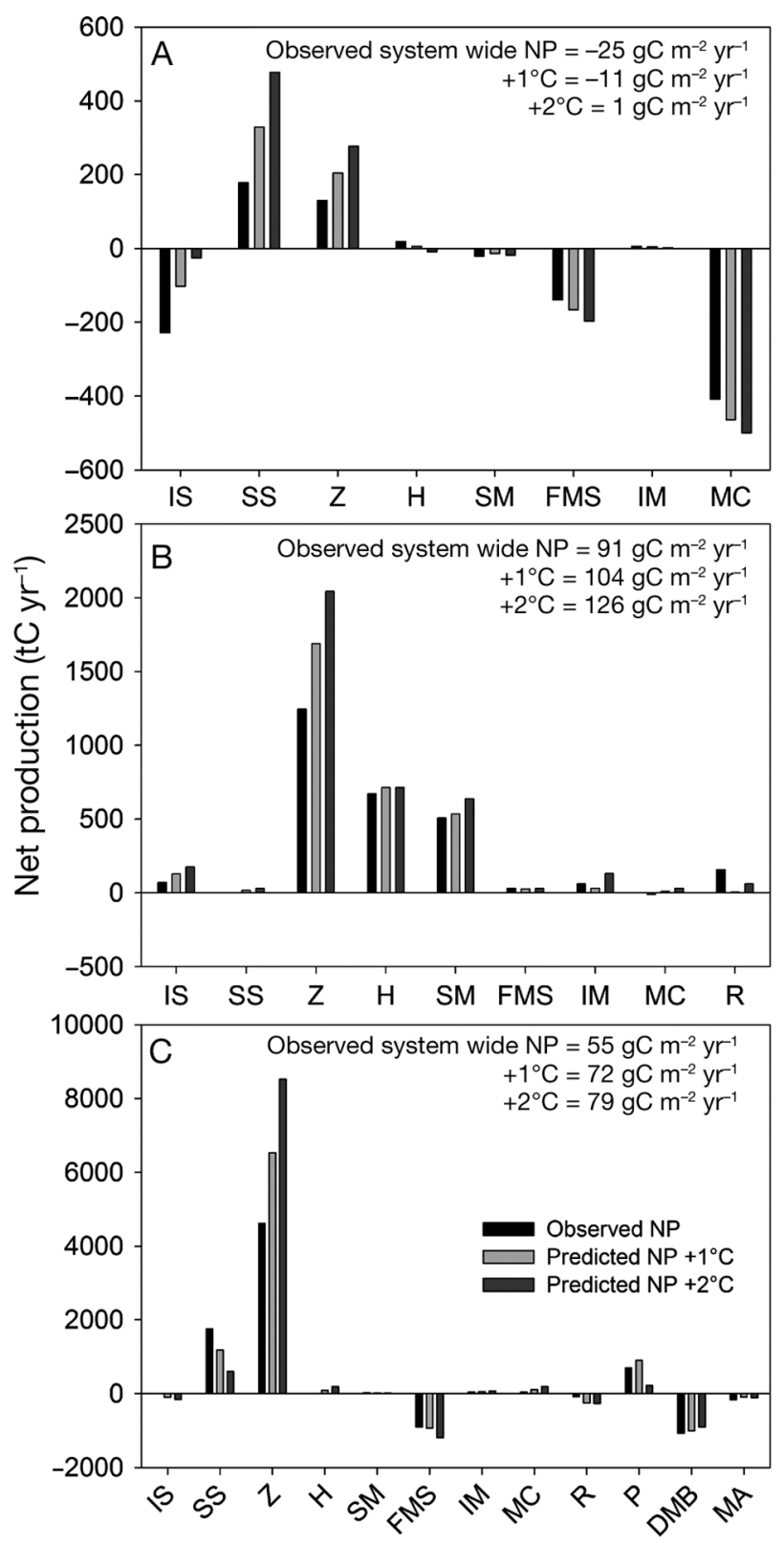

Fig. 4. ANN model predictions of changes in NP with a $1^{\circ} \mathrm{C}$ and $2^{\circ} \mathrm{C}$ increase in water temperature in (A) Hastings River, (B) Camden Haven, and (C) Wallis Lake

Obviously other system changes may occur that could influence rates of benthic GPP and R. For example, if the phytoplankton displayed a similar response to increases in temperature (i.e. increased rates of NP), inputs of labile organic matter to the sediment may stimulate higher respiration rates (Ferguson et al. 2007). However, the model includes sediment organic matter concentration and a proxy measure of composition $\left(\mathrm{TO}^{13} \mathrm{C}\right)$, which varied seasonally during the present study, as did phytoplankton biomass and productivity (Maher \& Eyre unpubl.). Fur- 
ther, we only made predictions within the limits of the input data, indicating that other temperaturedependant processes were included in the model structure. Despite the large temporal and spatial variation in organic matter supply during the study period, the ANN models were very robust (Appendix 2), as such the model predictions for the temperature increase scenarios should be similarly robust.

\section{CONCLUSION}

Macrophyte habitats dominated benthic metabolism in the 3 southeast Australian estuaries studied, despite covering only 8 to $38 \%$ of the benthos. Metabolism in non-macrophyte habitats was driven by a large suite of physical and biological parameters, predominantly light, temperature, benthic algae biomass, and organic matter supply. Metabolism in macrophyte habitats was linked to light and temperature; however, the relationships were weaker than for non-macrophyte habitats. ANN models outperformed stepwise regression methods for modelling GPP, R, and NP in both macrophyte and nonmacrophyte habitats. Model outputs for a predicted 1 to $2^{\circ} \mathrm{C}$ rise in estuary temperature indicate that benthic NP will increase, which will enhance carbon burial and export.

Acknowledgements. We thank Peter Squire, Melissa Bautista, Joanne Oakes, Tony Browne, and Dirk Erler for assistance with fieldwork. Joanne Oakes and Isaac Santos provided useful comments on the manuscript. We also thank 3 anonymous reviewers and the associate editor, whose comments helped improve this manuscript. This study was funded by Port Macquarie Hastings Council and an Australian Postgraduate Award (APA) awarded to D.M., and ARC Discovery (DP0342956) and ARC Linkage (LP0212073) grants awarded to B.E.

\section{LITERATURE CITED}

- Aller RC, Aller JY (1998) The effect of biogenic irrigation intensity and solute exchange on diagenic reaction rates in marine sediments. J Mar Res 56:905-936

Anderson LG, Hall POJ, Iverfeldt $\AA$, Rutgers van der Loeff MM, Sundby B, Westerlund SFG (1986) Benthic respiration measured by total carbonate production. Limnol Oceanogr 31:319-329

> Barciela RM, García E, Fernández E (1999) Modelling primary production in a coastal emabayment affected by upwelling using dynamic ecosystem models and artificial neural networks. Ecol Model 120:199-211

Barrón C, Marbà N, Terrados J (2004) Community metabolism and carbon budget along a gradient of seagrass (Cymodocea nodosa) colonization. Limnol Oceanogr 49: 1642-1651
Barrón C, Duarte CM, Frankignoulle M, Borges AV (2006) Organic carbon metabolism and carbonate dynamics in a Mediterranean seagrass (Posidonia oceanica) meadow. Estuaries Coasts 29:417-426

- Belgrano A, Malmgren BA, Lindahl O (2001) Application of artificial neural networks (ANN) to primary production time-series data. J Plankton Res 23:651-658

- Berelson WM, McManus J, Coale KH, Johnson KS, Kilgore T, Burdige D, Pilskaln C (1996) Biogenic matter diagenesis on the sea floor: a comparison between two continental margin transects. J Mar Res 54:731-762

> Berelson WM, Heggie D, Longmore A, Kilgore T, Nicholson G, Skyring G (1998) Benthic nutrient recycling in Port Phillip Bay, Australia. Estuar Coast Shelf Sci 46:917-934

Bishop C (1995) Neural networks for pattern recognition Oxford University Press, Oxford

Borum J, Sand-Jensen K (1996) Is total primary production in shallow coastal marine waters stimulated by nitrogen loading? Oikos 76:406-410

Cahoon LB (1999) The role of benthic microalgae in neritic ecosystems. Oceanogr Mar Biol Annu Rev 37:47-86

> Cebrian J (2002) Variability and control of carbon consumption, export, and accumulation in marine communities. Limnol Oceanogr 47:11-22

Costanza R, d'Arge R, de Groot R, Farber S and others (1997) The value of the world's ecosystem services and natural capital. Nature 387:253-260

$>$ D'Andrea AF, DeWitt TH (2009) Geochemical ecosystem engineering by the mud shrimp Upogebia pugettensis (Crustacea: Thalassinidae) in Yaquina Bay, Oregon: density-dependant effects on organic matter remineralisation and nutrient cycling. Limnol Oceanogr 54: 1911-1932

Dalsgaard T, Nielsen LP, Brotas V, Viaroli P and others (2000) Protocol handbook for NICE - nitrogen cycling in estuaries: a project under the EU Research ProgramMarine Science and Technology (MAST III). National Environmental Research Institute, Silkeborg

Diaz RJ, Rosenberg R (1995) Marine benthic hypoxia: a review of its ecological effects and the behavioural responses of benthic macrofauna. Oceanogr Mar Biol Annu Rev 33:245-303

> Duarte CM (1991) Allometric scaling of seagrass form and productivity. Mar Ecol Prog Ser 77:289-300

> Duarte CM, Cebrian J (1996) The fate of marine autotrophic production. Limnol Oceanogr 41:1758-1766

> Duarte CM, Benavent E, Sánchez MC (1999) The microcosm of particles within seagrass Posidonia oceanica canopies. Mar Ecol Prog Ser 181:289-295

> Duarte CM, Middleburg JJ, Caraco N (2005) Major role of marine vegetation on the oceanic carbon cycle. Biogeosciences 2:1-8

> Duarte CM, Marbá N, Gacia E, Fourqurean JW, Beggins J, Barrón C, Apostolaki ET (2010) Seagrass community metabolism: assessing the carbon sink capacity of seagrass meadows. Global Biogeochem Cycles 24, GB4032, doi:10.1029/2010GB003793

> Enríquez S, Rodríguez-Román A (2006) Effect of water flow on the photosynthesis of three marine macrophytes from a fringing-reef lagoon. Mar Ecol Prog Ser 323:119-132

> Epping EHG, Jørgensen BB (1996) Light-enhanced oxygen respiration in benthic phototrophic communities. Mar Ecol Prog Ser 139:193-203

Eyre BD (1995) A first-order nutrient budget for the tropical Moresby Estuary and catchment North Queensland, 
Australia. J Coast Res 11:717-732

Eyre BD, Ferguson AJP (2002) Comparison of carbon production and decomposition, benthic nutrient fluxes and denitrification in seagrass, phytoplankton, benthic microalgal and macroalgal dominated warm temperate Australian lagoons. Mar Ecol Prog Ser 229:43-59

Eyre BD, Ferguson AJP (2009) Denitrification efficiency for defining critical loads of carbon in shallow coastal ecosystems. Hydrobiologia 629:137-146

Eyre BD, Maher D (2010) Structure and function of warm temperate east Australian coastal lagoons: implications for natural and anthropogenic change. In: Kennish M, Paerl HW (eds) Coastal lagoons: systems of natural and anthropogenic change. CRC Press, Boca Raton, FL, p 457-481

Eyre BD, Maher D (2011) Mapping ecosystem processes and function across shallow seascapes. Cont Shelf Res 31: S162-S172

Eyre BD, Ferguson AJP, Webb AP, Maher D, Oakes JM (2011) Metabolism of different benthic habitats and their contribution to the carbon budget of a shallow oligotrophic subtropical coastal system. Biogeochemistry 102: 87-110

> Ferguson AJP, Eyre BD, Gay JM (2003) Organic matter and benthic metabolism in euphotic sediments along shallow sub-tropical estuaries, northern New South Wales, Australia. Aquat Microb Ecol 33:137-154

> Ferguson AJP, Eyre BD, Gay J (2004) Benthic nutrient fluxes in euphotic sediments along shallow sub-tropical estuaries, northern NSW, Australia. Aquat Microb Ecol 37: 219-235

Ferguson AJP, Eyre BD, Gay J, Emtage N, Brooks L (2007) Benthic metabolism and nitrogen cycling in a subtropical coastal embayment: spatial and seasonal controlling factors. Aquat Microb Ecol 48:175-195

Flood I, Kartam N (1994) Neural networks in civil engineering. I. Principles and understanding. J Comput Civ Eng 8:131-148

> Gattuso JP, Frankignoulle M, Wollast R (1998) Carbon and carbonate metabolism in coastal aquatic ecosystems. Annu Rev Ecol Syst 29:405-434

Gazeau F, Smith SV, Gentili B, Frankignoulle M, Gattuso JP (2004) The European coastal zone: characterization and first assessment of ecosystem metabolism. Estuar Coast Shelf Sci 60:673-694

Gazeau F, Duarte CM, Gattuso JP, Barron C and others (2005) Whole-system metabolism and $\mathrm{CO}_{2}$ fluxes in a Mediterranean Bay dominated by seagrass beds (Palma Bay, NW Mediterranean). Biogeosciences 2:43-60

Gribsholt B, Kristensen E (2003) Benthic metabolism and sulfur cycling along an inundation gradient in a tidal Spartina anglica salt marsh. Limnol Oceanogr 48: 2151-2162

Hauxwell J, Valiela I (2004) Effects of nutrient loading on shallow seagrass dominated coastal systems: patterns and processes. In: Nielsen SL, Banta G, Pedersen MF (eds) Estuarine nutrient cycling: the influence of primary producers. Kluwer Academic, Dordrecht, p 59-92

Heip CHR, Goosen NK, Herman PMJ, Kromkamp J, Middelburg JJ, Soetaert K (1995) Production and consumption of biological particles in temperate tidal estuaries. Oceanogr Mar Biol Annu Rev 33:1-149

Hemminga MA, Duarte CM (2000) Seagrass ecology, Cambridge University Press, Cambridge

> Hemminga MA, Harrison PG, van Lent F (1991) The balance of nutrient losses and gains in seagrass meadows. Mar
Ecol Prog Ser 71:85-96

Hopkinson CS, Smith EM (2005) Estuarine respiration an overview of benthic pelagic, and whole system respiration. In: del Giorgio PA, Williams PJIB (eds) Respiration in aquatic ecosystems. Oxford University Press, Oxford, p 123-146

Hughes JE, Deegan LA, Wyda JC, Weaver MJ, Wright A (2002) The effects of eelgrass habitat loss on estuarine fish communities of southern New England. Estuaries 25: 235-249

Ibarra-Obando SE, Smith SV, Poumian-Tapia M, CamachoIbar V, Carriquiry JD, Montes-Hugo M (2004) Benthic metabolism in San Quintin Bay, Baja California, Mexico. Mar Ecol Prog Ser 283:99-112

Jeffrey SW, Welschmeyer NA (1997) Spectrophotometric and fluorometric equations in common use in oceanography. In: Jeffrey SW, Mantoura RFC, Wright SW (eds) Phytoplankton pigments in oceanography: guidelines to modern methods. UNESCO Publishing, Paris, p 597-615

> Jenkins GP, May HMA, Wheatley MJ, Holloway MG (1997) Comparison of fish assemblages associated with seagrass and adjacent unvegetated habitats of Port Phillip Bay and Corner Inlet, Victoria, Australia, with emphasis on commercial species. Estuar Coast Shelf Sci 44:569-588

Kaldy JE, Onuf CP, Eldridge PM, Cifuentes LA (2002) Carbon budget for a subtropical seagrass dominated Lagoon: how important are seagrasses to total ecosystem net primary production? Estuaries 25:528-539

Kemp WM, Boynton WR (1980) Influence of biological and physical processes on dissolved oxygen dynamics in an estuarine system: implications for measurement of community metabolism. Estuar Coast Mar Sci 11:407-431

> Kirk JTO (1977) Attenuation of light in natural waters. Aust J Mar Freshwater Res 28:497-508

Kirk JTO (1983) Light and photosynthesis in aquatic ecosystems. Cambridge University Press, Cambridge

> Kowalski JL, DeYoe HR, Allison TC (2009) Seasonal production and biomass of the seagrass, Halodule wrightii Aschers (shoal grass) in a subtropical Texas lagoon. Estuaries Coasts 32:467-482

Kristensen E, Blackburn TH (1987) The fate of organic carbon and nitrogen in experimental marine sediment systems: influence of bioturbation and anoxia. J Mar Res 45: 231-257

> Lee KS, Park SR, Kim YK (2007) Effects of irradiance, temperature, and nutrients on growth dynamics of seagrasses: a review. J Exp Mar Biol Ecol 350:144-175

> Lek S, Delacoste M, Baran P, Dimopoulos I, Lauga J, Aulagnier S (1996) Application of neural networks to modelling nonlinear relationships in ecology. Ecol Model 90:39-52

> MacIntyre HL, Geider RJ, Miller DC (1996) Microphytobenthos: the ecological role of the 'Secret Garden' of unvegetated, shallow-water marine habitats. I. Distribution, abundance and primary production. Estuaries 19: 186-201

Maher D, Eyre BD (2010) Benthic fluxes of dissolved organic carbon in three temperate Australian estuaries: implications for global estimates of benthic DOC fluxes. J Geophys Res 115, G04039, doi:10.1029/2010JG001433

> Maher D, Eyre BD (2011) Insights into estuarine benthic dissolved organic carbon (DOC) dynamics using $\delta^{13} \mathrm{C}$ DOC values, phospholipid fatty acids and dissolved organic nutrient fluxes. Geochim Cosmochim Acta 75: 1889-1902 
Maier HR, Dandy GC (2000) Neural networks for the prediction and forecasting of water resources variables: a review of modelling issues and applications. Environ Model Softw 15:101-124

Mann KH (1988) Production and use of detritus in various freshwater, estuarine, and coastal marine ecosystems. Limnol Oceanogr 33:910-930

> Marinelli RL, Williams TJ (2003) Evidence for densitydependent effects of infauna on sediment biogeochemistry and benthic-pelagic coupling in nearshore systems. Estuar Coast Shelf Sci 57:179-192

Marsh JA, Dennison WC, Alberte RS (1986) Effects of temperature on photosynthesis and respiration in eelgrass (Zostera marina L.). J Exp Mar Biol Ecol 101:257-267

> McClelland JW, Valiela I (1998) Changes in food web structure under the influence of increased anthropogenic nitrogen inputs to estuaries. Mar Ecol Prog Ser 168: 259-271

McGlathery KJ, Sundback K, Anderson IC (2007) Eutrophication in shallow coastal bays and lagoons: the role of plants in the coastal filter. Mar Ecol Prog Ser 348:1-18

Millero FJ, Graham TB, Huang F, Bustos-Serrano H, Pierrot D (2006) Dissociation constants of carbonic acid in seawater as a function of salinity and temperature. Mar Chem 100:80-94

Millie DF, Weckman GR, Paerl HW, Pinckney JL, Bendis BJ, Pigg RJ, Fahnenstiel GL (2006) Neural net modeling of estuarine indicators: hindcasting phytoplankton biomass and net ecosystem production in the Neuse (North Carolina) and Trout (Florida) Rivers, USA. Ecol Indic 6: 589-608

Minns AW, Hall MJ (1996) Artificial neural networks as rainfall-runoff models. Hydrol Sci J 41:399-417

Moncreiff CA, Sullivan MJ, Daehnick AE (1992) Primary production dynamics in seagrass beds of Mississippi Sound: the contributions of seagrass, epiphytic algae, sand microflora, and phytoplankton. Mar Ecol Prog Ser 87:161-171

Papadimitriou S, Kennedy H, Kennedy DP, Duarte CM, Marba N (2005) Sources of organic matter in seagrasscolonized sediments: a stable isotope study of the silt and clay fraction from Posidonia oceanica meadows in the western Mediterranean. Org Geochem 36:949-961

Peralta G, Brun FG, Pérez-Lloréns JL, Bouma TJ (2006) Direct effects of current velocity on the growth, morphometry and architecture of seagrasses: a case study on Zostera noltii. Mar Ecol Prog Ser 327:135-142

Pihl L, Baden S, Kautsky N, Rönnbäck P, Söderqvist T, Troell M, Wennhage H (2006) Shift in fish assemblage structure due to loss of seagrass Zostera marina habitats in Sweden. Estuar Coast Shelf Sci 67:123-132

Pinckney JL, Zingmark RG (1993) Modeling the annual production of intertidal benthic microalgae in estuarine ecosystems. J Phycol 29:396-407

Rochelle-Newall EJ, Winter C, Barron C, Borges AV and others (2007) Artificial neural network analysis of factors controlling ecosystem metabolism in coastal systems. Ecol Appl 17:S185-S196

Roy PS, Williams RJ, Jones AR, Yassini I and others (2001) Structure and function of south-east Australian estuaries. Estuar Coast Shelf Sci 53:351-384

Rumelhart DE, Hinton GE, Williams RJ (1986) Learning representations by back-propagating errors. Nature 323: 533-536

Santos R, Silva J, Alexandre A, Navarro N, Barron C, Duarte CM (2004) Ecosystem metabolism and carbon fluxes of a tidally-dominated coastal lagoon. Estuaries 27:977-985

SAS (2007) JMP Statistics and graphics guide, Release 7, SAS Institute, Cary

> Scardi M (1996) Artificial neural networks as emperical models for estimating phytoplankton production. Mar Ecol Prog Ser 139:289-299

> Scardi M, Harding LW Jr (1999) Developing an empirical model of phytoplankton primary production: a neural network case study. Ecol Model 120:213-223

Smith SV, Veeh HH (1989) Mass balance of biogeochemically active materials $(\mathrm{C}, \mathrm{N}, \mathrm{P})$ in a hypersaline gulf. Estuar Coast Shelf Sci 29:195-215

- Smith SV, Hollibaugh JT (1993) Coastal metabolism and the oceanic organic carbon balance. Rev Geophys 31:75-89

Strickland JDH, Parsons TR (1972) A practical handbook for sea-water analysis, 2nd edn. Bulletin 167, Fisheries Research Board of Canada, Ottawa

Stumm W, Morgan JJ (1996) Aquatic chemistry: chemical equilibria and rates in natural waters. John Wiley and Sons, New York

> Stutes J, Cebrian J, Stutes AL, Hunter A, Corcoran AA (2007) Benthic metabolism across a gradient of anthropogenic impact in three shallow coastal lagoons in NW Florida. Mar Ecol Prog Ser 348:55-70

Underwood GJC, Kromkamp J (1999) Primary production by phytoplankton and microphytobenthos in estuaries. Adv Ecol Res 29:93-153

- Webb AP, Eyre BD (2004a) Effect of natural populations of burrowing thalassinidean shrimp on sediment irrigation, benthic metabolism, nutrient fluxes and denitrification. Mar Ecol Prog Ser 268:205-220

Webb AP, Eyre BD (2004b) The effects of two benthic chamber stirring systems on the diffusive boundary layer, oxygen flux, and passive flow through model macrofauna burrows. Estuaries 27:352-361

- Whitehead PG, Howard A, Arulmani C (1997) Modelling algal growth and transport in rivers: a comparison of time series analysis, dynamic mass balance and neural network techniques. Hydrobiologia 349:39-46

> Ziegler S, Benner R (1999) Dissolved organic carbon cycling in a subtropical seagrass-dominated lagoon. Mar Ecol Prog Ser 180:149-160

> Zimmerman RC, Cabello-Pasini A, Alberte RS (1994) Modelling daily production of aquatic macrophytes from irradiance measurements: a comparative analysis. Mar Ecol Prog Ser 114:185-196 


\begin{tabular}{|c|c|c|c|}
\hline 妾 & 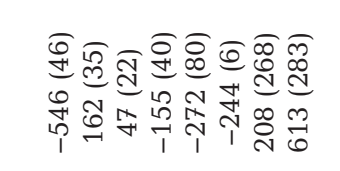 & 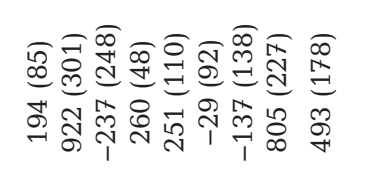 & 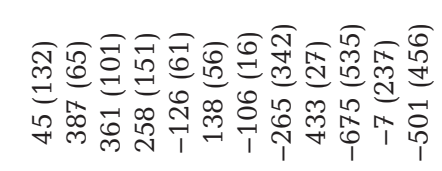 \\
\hline 焉 &  & 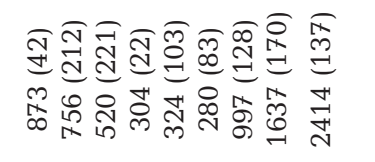 & 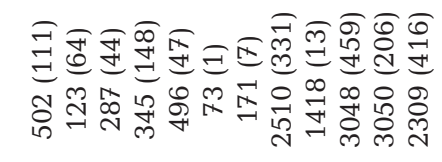 \\
\hline 芫 & 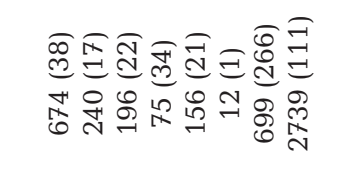 & 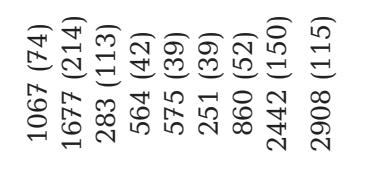 & 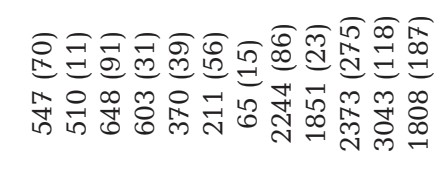 \\
\hline 宗 & 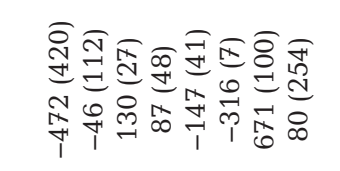 & 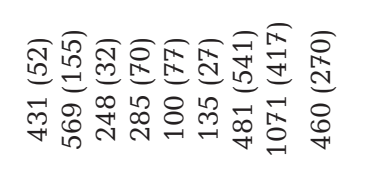 & 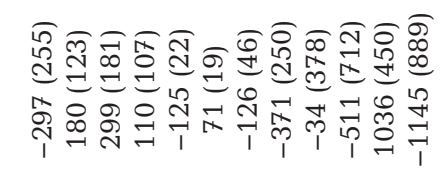 \\
\hline 节 &  & 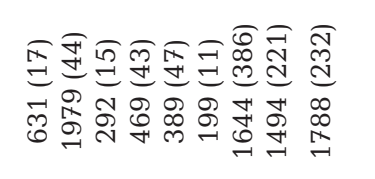 & 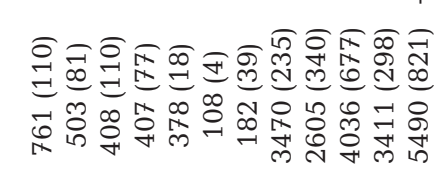 \\
\hline 莕 &  & 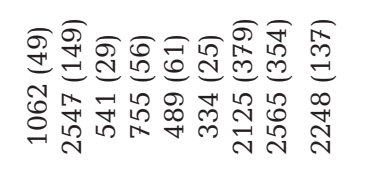 & 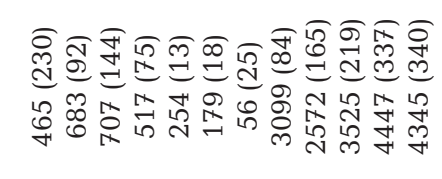 \\
\hline 宗 &  & 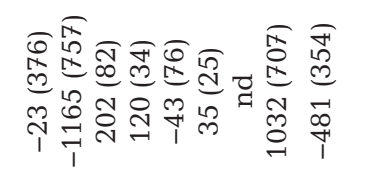 & 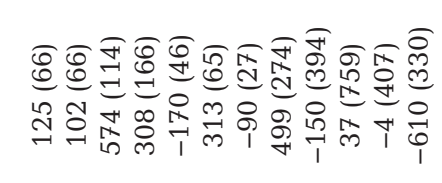 \\
\hline 跑, 幽 & 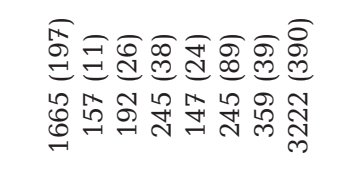 & 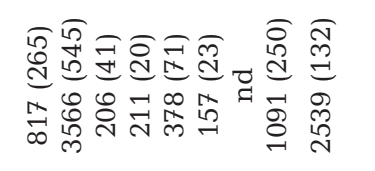 & 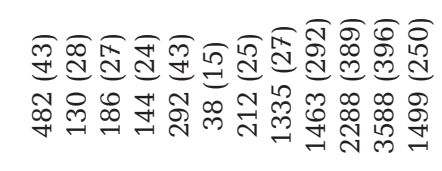 \\
\hline 荇 & 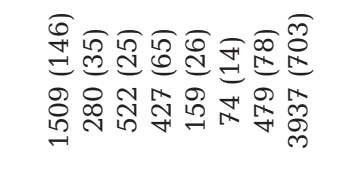 & 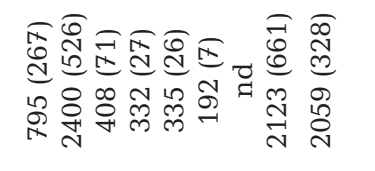 & 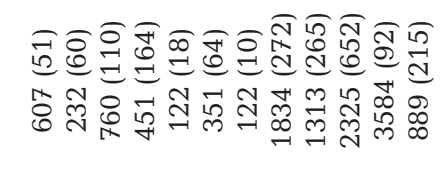 \\
\hline 文 & 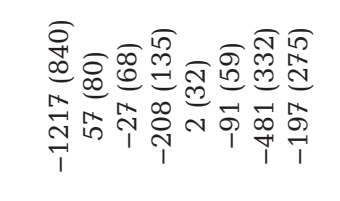 & 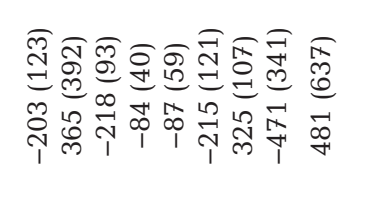 & 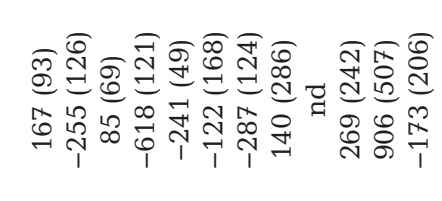 \\
\hline 幽 & 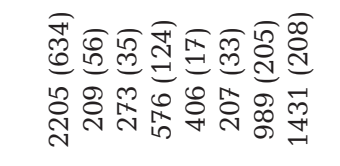 & 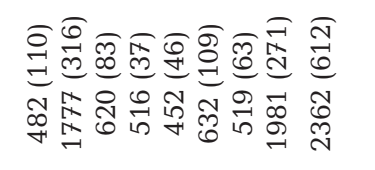 & 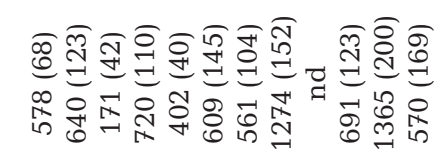 \\
\hline 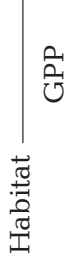 & 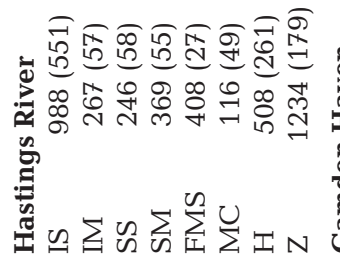 & 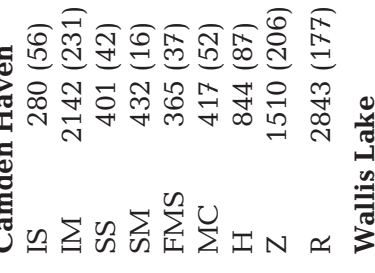 & 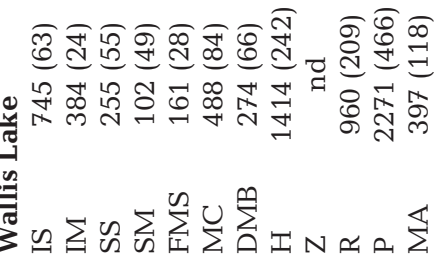 \\
\hline
\end{tabular}


Appendix 2. Results from ANN modelling. Variable selection methods: PC: principal component; MR: multiple regression; All: all variables. See Tables 2 \& 3 for additional abbreviations

\begin{tabular}{|c|c|c|c|c|c|c|}
\hline & Nodes & $\begin{array}{c}\text { Training } \\
\mathrm{R}^{2}\end{array}$ & $\begin{array}{c}\text { Cross } \\
\text { validation } \\
\mathrm{R}^{2}\end{array}$ & $\begin{array}{c}\mathrm{RMSE} \\
\left(\mathrm{mgC} \mathrm{d}^{-1}\right)\end{array}$ & $\begin{array}{c}\text { Variable } \\
\text { selection } \\
\text { method }\end{array}$ & Variables \\
\hline \multicolumn{7}{|c|}{ Non-macrophyte } \\
\hline $\operatorname{GPP}\left(\mathrm{O}_{2}\right)$ & 10 & 0.900 & 0.743 & 131 & $\mathrm{PC}$ & TOC, light, TN, chl $a, \operatorname{chl} c, \mathrm{~T}^{15} \mathrm{~N}$ \\
\hline $\operatorname{GPP}\left(\mathrm{O}_{2}\right)$ & 10 & 0.887 & 0.833 & 113 & MR & Chl $c$, light, $\mathrm{kd}, \mathrm{chl} b$, temp \\
\hline $\operatorname{GPP}\left(\mathrm{O}_{2}\right)$ & 7 & 0.981 & 0.886 & 61 & All & $\begin{array}{l}\text { Light, kd, temp, salinity, dis, } \mathrm{TO}^{13} \mathrm{C} \text {, } \\
\text { TOC, } \mathrm{T}^{15} \mathrm{~N}, \text { Pheo, chl } a, \operatorname{chl} b, \operatorname{chl} c\end{array}$ \\
\hline $\operatorname{GPP}\left(\mathrm{TCO}_{2}\right)$ & 9 & 0.804 & 0.647 & 173 & $\mathrm{PC}$ & TOC, light, TN, chl $a, \operatorname{chl} c, \mathrm{~T}^{15} \mathrm{~N}$ \\
\hline $\mathrm{GPP}\left(\mathrm{TCO}_{2}\right)$ & 10 & 0.821 & 0.647 & 169 & MR & Chl $c$, light, kd, salinity, $\operatorname{chl} b$ \\
\hline $\operatorname{GPP}\left(\mathrm{TCO}_{2}\right)$ & 8 & 0.977 & 0.777 & 95 & All & $\begin{array}{l}\text { Light, kd, temp, salinity, dis, } \mathrm{TO}^{13} \mathrm{C} \text {, } \\
\text { TOC, } \mathrm{T}^{15} \mathrm{~N}, \text { Pheo, chl } a, \operatorname{chl} b, \operatorname{chl} c\end{array}$ \\
\hline $\mathrm{R}\left(\mathrm{O}_{2}\right)$ & 9 & 0.892 & 0.665 & 78 & $\mathrm{PC}$ & TOC, $\mathrm{T}^{15} \mathrm{~N}$, pheo, chl $a$, TN, temp \\
\hline $\mathrm{R}\left(\mathrm{O}_{2}\right)$ & 8 & 0.758 & 0.630 & 108 & $\mathrm{MR}$ & Pheo, temp, salinity, chl $b$ \\
\hline $\mathrm{R}\left(\mathrm{O}_{2}\right)$ & 10 & 0.990 & 0.768 & 45 & All & $\begin{array}{l}\text { Light, } \mathrm{kd} \text {, temp, salinity, dis, } \mathrm{TO}^{13} \mathrm{C} \text {, } \\
\text { TOC, } \mathrm{T}^{15} \mathrm{~N}, \text { Pheo, chl } a, \operatorname{chl} b, \operatorname{chl} c\end{array}$ \\
\hline $\mathrm{R}\left(\mathrm{TCO}_{2}\right)$ & 9 & 0.747 & 0.475 & 170 & $\mathrm{PC}$ & TOC, $\mathrm{T}^{15} \mathrm{~N}$, pheo, chl $a, \mathrm{TN}$, temp \\
\hline $\mathrm{R}\left(\mathrm{TCO}_{2}\right)$ & 10 & 0.571 & 0.417 & 208 & MR & Pheo, salinity, kd, chl a \\
\hline $\mathrm{R}\left(\mathrm{TCO}_{2}\right)$ & 8 & 0.940 & 0.660 & 134 & All & $\begin{array}{l}\text { Light, kd, temp, salinity, dis, } \mathrm{TO}^{13} \mathrm{C} \text {, } \\
\text { TOC, } \mathrm{T}^{15} \mathrm{~N} \text {, Pheo, chl } a \text {, chl } b \text {, chl } c\end{array}$ \\
\hline $\mathrm{NP}\left(\mathrm{O}_{2}\right)$ & 10 & 0.852 & 0.692 & 154 & $\mathrm{PC}$ & Light, TOC, $\mathrm{T}^{15} \mathrm{~N}, \operatorname{chl} a_{,} \operatorname{chl} c$ \\
\hline $\mathrm{NP}\left(\mathrm{O}_{2}\right)$ & 10 & 0.896 & 0.813 & 125 & $\mathrm{MR}$ & Chl $c$, light, pheo, chl $b$, kd, salinity \\
\hline $\mathrm{NP}\left(\mathrm{O}_{2}\right)$ & 8 & 0.990 & 0.867 & 66 & All & $\begin{array}{l}\text { Light, kd, temp, salinity, dis, } \mathrm{TO}^{13} \mathrm{C} \text {, } \\
\text { TOC, } \mathrm{T}^{15} \mathrm{~N}, \text { Pheo, chl } a, \mathrm{chl} b, \mathrm{chl} c\end{array}$ \\
\hline $\mathrm{NP}\left(\mathrm{TCO}_{2}\right)$ & 10 & 0.816 & 0.569 & 169 & $\mathrm{PC}$ & Light, TOC, TN, ${ }^{15} \mathrm{~N}, \operatorname{chl} a, \operatorname{chl} c$ \\
\hline $\mathrm{NP}\left(\mathrm{TCO}_{2}\right)$ & 10 & 0.800 & 0.658 & 208 & MR & Chl $c$, light, pheo, kd, chl $b$ \\
\hline $\mathrm{NP}\left(\mathrm{TCO}_{2}\right)$ & 8 & 0.976 & 0.732 & 99 & All & $\begin{array}{l}\text { Light, kd, temp, salinity, dis, } \mathrm{TO}^{13} \mathrm{C} \text {, } \\
\text { TOC, } \mathrm{T}^{15} \mathrm{~N}, \text { Pheo, chl } a, \operatorname{chl} b, \mathrm{chl} c\end{array}$ \\
\hline \multicolumn{7}{|l|}{ Macrophyte } \\
\hline $\operatorname{GPP}\left(\mathrm{O}_{2}\right)$ & 5 & 0.575 & 0.568 & 1266 & $\mathrm{PC}$ & Light, $\mathrm{kd}$, temp, salinity \\
\hline $\operatorname{GPP}\left(\mathrm{O}_{2}\right)$ & 10 & 0.483 & 0.501 & 1520 & MR & Temp, salinity \\
\hline GPP $\left(\mathrm{O}_{2}\right)$ & 10 & 0.979 & 0.755 & 560 & All & $\begin{array}{l}\text { Light, } \mathrm{kd} \text {, temp, salinity, dis, } \mathrm{TO}^{13} \mathrm{C} \text {, } \\
\text { TOC, } \mathrm{T}^{15} \mathrm{~N}, \text { Pheo, chl } a \text {, chl } b, \operatorname{chl} c\end{array}$ \\
\hline $\mathrm{GPP}\left(\mathrm{TCO}_{2}\right)$ & 6 & 0.540 & 0.431 & 1237 & $\mathrm{PC}$ & Light, kd, temp, salinity \\
\hline $\mathrm{GPP}\left(\mathrm{TCO}_{2}\right)$ & 6 & 0.726 & 0.502 & 823 & MR & Temp, light, pheo, \\
\hline GPP $\left(\mathrm{TCO}_{2}\right)$ & 10 & 0.975 & 0.676 & 771 & All & $\begin{array}{l}\text { Light, kd, temp, salinity, dis, } \mathrm{TO}^{13} \mathrm{C} \text {, } \\
\text { TOC, } \mathrm{T}^{15} \mathrm{~N}, \text { Pheo, chl } a, \operatorname{chl} b, \mathrm{chl} c\end{array}$ \\
\hline $\mathrm{R}\left(\mathrm{O}_{2}\right)$ & 3 & 0.716 & 0.706 & 754 & $\mathrm{PC}$ & Light, kd, temp \\
\hline $\mathrm{R}\left(\mathrm{O}_{2}\right)$ & 3 & 0.899 & 0.771 & 568 & MR & Salinity, temp, dis, light, pheo \\
\hline $\mathrm{R}\left(\mathrm{O}_{2}\right)$ & 10 & 0.999 & 0.881 & 300 & All & $\begin{array}{l}\text { Light, kd, temp, salinity, dis, } \mathrm{TO}^{13} \mathrm{C} \text {, } \\
\text { TOC, } \mathrm{T}^{15} \mathrm{~N} \text {, Pheo, chl } a \text {, chl } b \text {, chl } c\end{array}$ \\
\hline $\mathrm{R}\left(\mathrm{TCO}_{2}\right)$ & 3 & 0.683 & 0.670 & 1286 & $\mathrm{PC}$ & Light, kd, temp \\
\hline $\mathrm{R}\left(\mathrm{TCO}_{2}\right)$ & 5 & 0.594 & 0.559 & 1450 & MR & Light, temp, salinity \\
\hline $\mathrm{R}\left(\mathrm{TCO}_{2}\right)$ & 10 & 0.976 & 0.808 & 567 & All & $\begin{array}{l}\text { Light, kd, temp, salinity, dis, } \mathrm{TO}^{13} \mathrm{C} \text {, } \\
\text { TOC, } \mathrm{T}^{15} \mathrm{~N}, \text { Pheo, chl } a, \operatorname{chl} b, \mathrm{chl} c\end{array}$ \\
\hline $\mathrm{NP}\left(\mathrm{O}_{2}\right)$ & 8 & 0.844 & 0.508 & 399 & $\mathrm{PC}$ & Temp, $\mathrm{TO}^{13} \mathrm{C}$, pheo, light \\
\hline $\mathrm{NP}\left(\mathrm{O}_{2}\right)$ & 10 & 0.400 & 0.400 & 834 & MR & Temp, dis, kd \\
\hline $\mathrm{NP}\left(\mathrm{O}_{2}\right)$ & 6 & 0.999 & 0.640 & 62 & All & $\begin{array}{l}\text { Light, kd, temp, salinity, dis, } \mathrm{TO}^{13} \mathrm{C} \text {, } \\
\text { TOC, } \mathrm{T}^{15} \mathrm{~N} \text {, Pheo, chl } a \text {, chl } b, \operatorname{chl} c\end{array}$ \\
\hline $\mathrm{NP}\left(\mathrm{TCO}_{2}\right)$ & 4 & 0.699 & 0.550 & 608 & $\mathrm{PC}$ & Temp, $\mathrm{TO}^{13} \mathrm{C}$, pheo, light \\
\hline $\mathrm{NP}\left(\mathrm{TCO}_{2}\right)$ & 3 & 0.767 & 0.540 & 471 & $\mathrm{MR}$ & Dis, $\mathrm{TO}^{13} \mathrm{C}, \mathrm{T}^{15} \mathrm{~N}$, light \\
\hline $\mathrm{NP}\left(\mathrm{TCO}_{2}\right)$ & 6 & 0.956 & 0.587 & 387 & All & $\begin{array}{l}\text { Light, } \mathrm{kd} \text {, temp, salinity, dis, } \mathrm{TO}^{13} \mathrm{C} \text {, } \\
\text { TOC, } \mathrm{T}^{15} \mathrm{~N}, \text { Pheo, chl } a \text {, chl } b \text {, chl } c\end{array}$ \\
\hline
\end{tabular}

